\title{
A internacionalizaçâo do diálogo dos juízes: missiva ao Sr. Bruno Genevois, presidente do conselho de estado da França ${ }^{1}$
}

Laurence Burgorgue-Larsen²

\section{Resumo}

O presente artigo, convidado e traduzido pelo Editorial da revista Prismas, trata de um texto que discute o processo de internacionalização do direito. A autora segue um estilo lingüístico de carta, dirigido ao Presidente do Tribunal francês, considerado um dos responsáveis pelo avanço do processo de internacionalização. $\mathrm{O}$ artigo faz uma comparação entre os avanços no processo de internacionalização do direito da Corte Interamericana de Direitos Humanos e a Corte Européia de Direitos Humanos, em um contexto classificado como diálogo de juízes. Vários precedentes judiciais e lógicas são citadas e analisadas.

Palavras-chave: Internacionalização do Direito. Direitos Humanos. Diálogo dos Juízes.

\section{Prezado Presidente ${ }^{3}$,}

Quantas vezes eu falhei no meu dever de pegar uma caneta com as mãos que deveriam estar sempre inspiradas e alertas para responder às suas cartas, a cada vez que elas chegavam a mim, marcando o início de uma efervescente curiosidade intelectual. De fato, a cada vez que eu lhe enviava uma separata de um artigo, o senhor me respondia com seus comentários à mão, da mesma forma que a outros colegas, para mostrar suas observações sobre o artigo que eu lhe havia enviado, conforme aos usos e costumes do nosso "pequeno mundo" acadêmico.

1 Este artigo está cadastrado no Digital Object Identifier System sob o número doi: 10.5102/ prismas.2010.07.1.09 Disponível em: <www.publicaçõesacadêmicas.uniceub.br>.

2 Professora na Universidade Paris 1 Panthéon-Sorbonne

3 Eu me permito lhe tratar desta forma, uma vez que o senhor foi presidente da Seção de Contenciosos do Conselho de Estado. 
Deveria ter lhe agradecido por ter utilizado seu tempo para iniciar tantas conversas acadêmicas por meio de cartas; para iniciar, como eu diria, um "diálogo" no qual, normalmente, o senhor refutava - com argumentos arrasadores esta ou aquela observação que o senhor julgava intempestiva - ou ainda para concordar com as análises que lhe convenciam. Além disso, por ter sido aquele que vulgarizou na França a expressão "diálogo de juizes" - o senhor que o reafirmou no âmbito do Conselho de Estado de um diálogo constante, sem ser onipresente, aberto, sem ser complacente, crítico, sem desprezo, elogioso (por vez), sem ser pedante, com múltiplos representantes de diferentes gerações que compõem um universo acadêmico. Uma abertura de espírito remarcada e remarcável tanto quanto os códigos de nossas respectivas instituições podem ser marcados, pelo passado, por muitas manifestações de uma pouca empatia institucional. Eu aproveito esta bela ocasião que me é ofertada para lhe render uma homenagem à sua abertura de espírito. Ela se manifestou tanto em relação à abertura das ideias vindas de fora - aquelas que não germinaram no Palais Royal - como os "direitos vindos do estrangeiro", como o Decano Carbonnier dizia e considerava destrutivos - ainda que hoje em dia alguns professores insistam em pensar e ensinar o direito de uma forma "aprisionada”... Ora, hoje em dia, apegar-se a um olhar nacional do direito - que pode esconder um olhar nacionalista do direito - é algo sem sentido. O tempo do "mundo finito" é uma realidade que Paul Valéry já revelava em 1919.

Hoje em dia, podemos falar em um "mundo globalizado”. A globalização induz a uma internacionalização dos sistemas e dos comportamentos judiciários nacionais e numa "nacionalização" do direito e dos procedimentos internacionais que fazem parte hoje de outro tempo: o tempo decorrido. ${ }^{4}$

A expressão “internacionalização” é polissêmica e é importante apresentar o sentido que gostaria de atribuir a ela. . De fato, a expressão não terá necessariamente o mesmo significado para um constitucionalista - que não pode hoje em dia ignorar o fenômeno na internacionalização das constituições nacionais que se

\footnotetext{
4 Aqui se pensa imediatamente em Prosper Weil que analisa, em homenagem a Louis Trotabas - já há quase 38 anos (!) - três áreas (Direito das Comunidades Europeias, do serviço civil internacional e do Contencioso nacional nos tribunais administrativos) que permitiram ao direito administrativo francês ser "exportado" no mundo internacional, cf. DROIT international public et droit administratif. Paris: LGDJ, 1970. Mélanges offerts à Louis Trotabas p. 511-528.
} 
acumula, na Europa, a um processo de "europeização" - e para um internacionalista, que analisa o regime dos espaços particulares - como as cidades ou territórios - colocados sob a administração itnernacional ${ }^{5}$, como também das iniciativas espistemolóticas que não impedem os frutíferos encontros analíticos ${ }^{6}$.

No âmbito de meu propósito, a internacionalização do diálogo dos juízes é compreendida como sendo a manifestação do desemparedamento territorial do diálogo ${ }^{7}$. O juiz - se for e será sempre ligado a um território (para o juiz doméstico), assim como a processos e, in fine, a um sistema de normas específicas (para os juízes domésticos e internacionais) - é levado a se abrir a outros juízes ligados a outros universos sistêmicos. Essa noção de "abertura", confesso sem receio, não tem nada de jurídico. No entanto, ela permite abranger o amplo leque das manifestações tanto da internacionalização como tal, quanto do diálogo judicial que acontece num espaço em que as fronteiras territoriais, como as culturais, as linguísticas, as societais, recuam sempre cada vez mais. Não tenho nenhuma dúvida sobre o fato que minhas apreciações a respeito desse fenômeno suscitarão da sua parte, ao mesmo tempo, oposições e até (talvez) reprovações, e também espero, confirmações e pontos de acordo. Em outras palavras, todos os ingredientes estarão presentes para que o diálogo, assim estabelecido graças a sua constância epistolaria, prossiga. Sempre devemos lembrar que um "diálogo" - cujo nome está enraizado no latim dialogus, que remete a uma "conversa filosófica de acordo com a maneira dos

${ }_{5}$ Percorrendo o Dictionnaire de droit international public, encontrará cinco outros sentidos do conceito de "internacionalização" entendido no sentido do direito internacional, Cf. SALMON, Jean (Org.). Dictionnaire de droit international public. Paris: Bruylant, 2001. p. 600-601.

6 Penso, aqui, nas reflexões de Nicolas Maziau que, como constitucionalista, graças a suas funções em Bósnia-Herzegovina, observou de perto certos fenômenos característicos de "internacionalização", cf. MAZIAU, Nicolas. A internacionalização do poder constituinte: ensaio de tipologia, o ponto de vista heterodoxo do constitucionalista. RGDIP, Paris, p. 549-579, 2002-3. MARC, Besson (Col.). A Bósnia-Herzegovina futura doze anos após Dayton: mudanças esperadas e perspectivas. . Renouveau du droit constitutionnel: mélanges en l'honneur de Louis Favoreu. Paris: Dalloz, 2007. p. 837-856.

7 Da mesma maneira que o direito sai de suas fronteiras nacionais - o que é para Mireille Delmas-Marty a marca da "internacionalização do direito", o diálogo faz o mesmo. Eu lhe indico, a este respeito, sua lição inaugural no Collège de France, DELMAS-MARTY, Mireille. Etudes juridiques comparatives et internationalisation du droit. Paris: Fayard, 2003. 57 p. p. 13. 
diálogos de Platão"8 - é, antes de tudo, uma troca de pontos de vista, uma conversa, uma "conversa entre duas ou mais pessoas" 9 . Fazendo isso, ao contrário de um pensamento geral, ele induz tanto a oposição, a contradição e até a discórdia, como o acordo e a concordância; ele pode, principalmente, desenvolver-se entre mais de dois juízes diferentes: o diálogo pode ser tri, e até multidimensional. O diálogo não se manifesta exclusivamente no âmbito de um dueto jurisdicional. Ele pode se alimentar com múltiplas interações entre mais de dois juizes.

Caro Presidente, eu tinha que passar por este pequeno exercício de esclarecimento semântico de sua própria "fórmula”. Não é que estivesse "obscura” no momento em que a empregou no contexto muito particular da integração comunitária europeia. No entanto, ela recolheu tantos ecos doutrinais que se tornou quase impossível de se apanhar, o que é, sem dúvida, o resultado de um sucesso fulgurante. Muitos colóquios, livros, artigos a empregam (mas muitas vezes com sentidos diferentes), pelo fato de ser emblemática de uma nova configuração das relações entre instituições encarregadas de fazer a justiça. Certo, mas de qual configuração e quais instituições se tratam exatamente? Com efeito, saindo do postulado que o diálogo induz ao mesmo tempo a oposição - o desacordo, mas também o entendimento - a concordância, apesar de ter ainda que identificar os contextos nos quais as manifestações das discussões judiciais nascem e se desenvolvem.

Penso que estará de acordo comigo sobre o fato que a eclosão internacional do "comércio dos juízes"10 é um fenômeno fascinante e maior desde que o direito internacional foi apanhado por um grande brotamento jurisdicional ${ }^{11}$. $\mathrm{Na}$ era da centralização judicial encarnada sucessivamente pela Corte permanente de justi-

8 É o que lembra o Dictionnaire historique de la langue française publicado sob a direção de Alain Rey. Encontra-se na entrada "Decálogo" os elementos seguintes: primeiro dialogue (v.1200), é tomado emprestado ao latim dialogus "entrevista filosófica à maneira dos diálogos de Platão", emprestado do grego dialogos "entrevista, discussão", termo empregado primeiro pelos filósofos (Aristóteles e Platão) e derivado de dialegein "discutir".

9 Esta última fórmula é aquela do primeiro sentido dado pelo Littré: "(lat. dialogus), Conversa entre duas ou mais pessoas".

${ }^{10}$ Esta bela fórmula é aquela de Antoine Garapon e de Julie Allard que, com uma destreza analítica fora do comum, s’interessam, a sua maneira, ao lugar do juiz na globalização, cf. GARAPON, Antoine; ALLARD, Julie. Les juges dans la mondialisation: la nouvelle révolution du droit. Paris: Ed. du Seuil ; La République des idées, 2005. 96 p.

${ }^{11}$ Encontrará nos atos do colóquio de Lille da Sociedade Francesa para o direito internacional, comunicações refletindo os numerosos questionamentos decorrentes da multiplicação 
ça internacional, e a Corte internacional de justiça sucedeu a da centralização do poder de julgar na escala internacional. Automaticamente, isso deu "ao diálogo dos juízes" uma forma bem singular. Sem arriscar uma sistematização da questão (impossível no âmbito das poucas linhas desta carta), me pareceu, entretanto, que dois tipos de contextos permitiam o lançamento e o desenvolvimento de trocas de pontos de visto entre os juízes.

O primeiro tipo de diálogo se insere no seio de um "sistema" jurídico - mais ou menos sofisticado - apresenta a forma da verticalidade, na medida em que ele se elabora entre um juiz internacional e um juiz doméstico. Aqui, é um conjunto de vinculações processuais específicas oriundas dos sistemas internacionais que dominam as ordens jurídicas internas que vão obrigar os juízes, assentados nas duas margens do espaço jurídico: a margem nacional e a margem supranacional, a conversar.

O segundo tipo de diálogo se insere num espaço muito mais aberto, pelo fato de ser, em momento algum, ligado a um sistema específico. Aqui, juízes de todas as tendências se lançam em conversas judiciais na base de uma abertura espontânea ao mundo da justiça na sua globalidade internacional. O improviso epistolar judicial é obrigatório, mesmo se ele esconde, na realidade, múltiplos interesses. Estes juízes conversam quaisquer que sejam seus sistemas de pertencimento (internacional ou nacional) e seus ofícios (resolução dos litígios interestatais ou dos conflitos comerciais, sanção dos crimes internacionais, declaração das violações dos direitos do homem, controle de constitucionalidade, controle da ação administrativa, controle das ações dos particulares, etc.). Nos dois casos - que o diálogo seja orquestrado (I) ou sem nexo (II) - estas entrevistas judiciais tomam corpo concretamente de maneira idêntica. É o balé das referências a decisões de justiça "externas" (nacionais e/ou internacionais) que é a marca do diálogo judicial. Todavia,

das jurisdições internacionais cf. LA JURIDICTIONNALISATION du droit international. Paris: Pedone, 2003. 545 p. No seio da comunidade dos internacionalistas, o debate prossegue sobre as conseqüências deste fenômeno: alguns temem uma "fragmentação" do direito internacional resultando na sua "setorialização"; enquanto outros vêm nele a manifestação de uma legitimidade renovada. Isso conduziu a famosa Comissão para o direito internacional a adotar na sua $58^{\mathrm{a}}$ sessão as Conclusões dos trabalhos do grupo de estudo sobre A FRAGMENTAÇÃO do direito internacional: dificuldades decorrentes da diversificação e da expansão do direito internacional. In: Comissão do direito internacional, sessão $n^{\circ}$ 58, Genebra: Organização das Nações Unidas, 2006. 
veremos que se a materialização deste diálogo toma a mesma forma referencial, certamente ela não tem o mesmo sentido.

No momento em que você termina a leitura destas linhas de introdução, meu desejo mais forte é que entenda que não pude resistir à tentação (incontestavelmente bela demais) de homenageá-lo escrevendo-lhe uma carta doutrinal com símbolos múltiplos. Ela representa tanto sua participação pessoal ao diálogo dos juízes quanto aquele que você iniciou com a doutrina. Além disso, submetendo à sua enérgica sagacidade intelectual essas ideias sobre o fenômeno da "interpretação" do diálogo dos juízes, é também e, sobretudo, a continuidade de nossa própria correspondência sobre as variadas interações entre jurisdições que eu procuro aqui.

\section{0 diálogo orquestrado}

O senhor que lutou pelo diálogo no espaço bem particular da integração comunitária europeia, somente pode aderir à ideia que a rejeição inicial do que "vem de outro lugar” não tem, finalmente, nenhuma validade. Se o brilhante “ Dany o Vermelho" foi uma das figuras emblemáticas de uma juventude à procura de liberdade em maio de 1968, sobretudo, ele terá deixado seu nome nos anais judiciais do direito administrativo para a comunidade dos juristas franceses.

O caso Cohn-Bendit figura, com efeito, num lugar de destaque no seio das Grandes decisões da jurisprudência administrativa ${ }^{12}$, entre as clássicas das obras de direito público sobre o qual todos os estudantes, apaixonados pelo direito, somente passarão algumas belas horas na descoberta das arcanas da evolução jurisprudencial administrativa. Esse caso terá lhe dado a oportunidade, como Comissário do Governo $^{13}$, de se expressar no âmbito de um litígio em que o direito comunitário europeu brilhava intensamente e em que o reenvio prejudicial foi ativado pelo Tribunal administrativo de Paris. Sabemos até que ponto esse diálogo organizado, ou melhor, orquestrado entre as jurisdições nacionais e a Corte de justiça é vital para o desenvolvimento do processo de integração europeia. Esse diálogo integrado -

\footnotetext{
${ }^{12}$ Como aqui não destacar que esta obra foi, para mim, uma revelação no segundo ano de Direito; ganhava definitivamente meu gosto para o Direito Público.

${ }^{13}$ CE, Ass., 22 dezembro 1978, Ministro da Segurança Pública c. Cohn-Bendit, Rec. 524, concl. B. Genevois, Dalloz, 1979, p. 155.
} 
que se estabelece e se desenvolve num tipo de verticalidade sem hierarquia, pelo menos em teoria - é o cimento do entendimento jurisdicional indispensável para o desenvolvimento de uma integração harmoniosa, impregnada de interpretação e de aplicação uniformes do direito comunitário.

Mas, hoje, esse tipo de diálogo não é mais o privilégio do continente europeu. O processo de integração sendo múltiplo, prosperou com variações específicas nos países latino-americanos e africanos para a felicidade dos comparatistas do fenômeno integrativo. Outro aspecto da internacionalização em suma. A liberação "territorial” é, aqui, uma liberação "continental". Nascido no continente europeu, o diálogo integrado exportou-se, pois o mimetismo institucional se refletiu, sem falha, sobre o fenômeno jurisdicional.

Ao lado desse diálogo integrado, observamos aquele que se desenvolve no universo bem peculiar das convenções de proteção dos direitos humanos. A priori, é menos estruturado já que nenhuma disposição equivalente ao artigo 234 T. CE o regulamenta. Todavia, é induzido pela subsidariedade dos mecanismos de garantia coletiva que nomeia os juízes nacionais em "juiz convencional de direito comum”, para tomar emprestada uma famosa fórmula do vocabulário do direito comunitário. A despeito da ausência de uma institucionalização do "comércio" judiciário, é vivo e resistente e tem como consequência a metamorfose de todos os setores dos direitos nacionais, a tal ponto que os juízes se tornam os motores das mudanças normativas, e até societais, dos Estados partes nas Convenções de proteção. Amplamente conhecido e analisado na Europa, este diálogo convencional também ultrapassou as fronteiras do "Velho continente".

Ele também se desenvolve, hoje, no hemisfério sul entre os juízes dos Estados partes na Convenção Americana dos Direitos Humanos e a Corte Interamericana dos Direitos do Homem, colega demasiadamente pouco conhecida por parte da Corte de Estrasburgo. Não vai deixar de se desenvolver sobre o continente africano quando a interposição da ação junto à Corte Africana dos Direitos Humanos e dos Povos será efetivada ${ }^{14}$.

\footnotetext{
${ }^{14}$ A Corte Africana dos Direitos Humanos e dos Povos foi criada pelo Protocolo dito de "Ouagadougou”, o chamado Protocolo relativo à Carta africana dos direitos humanos e dos povos, realizando a criação de uma Corte africana dos direitos humanos e dos povos.
} 


\section{0 diálogo integrado}

Trata-se, no leque das múltiplas manifestações do diálogo dos juízes, da figura mais bem sucedida pelo fato de ser enquadrada e organizada - em uma palavra, institucionalizada - através de uma disposição específica de um tratado internacional: o famoso artigo 234 do tratado instaurando a Comunidade europeia ${ }^{15}$. Nele, a orquestração processual é magistral, a ponto de impor ao juiz, que atua em última instância, o reenvio de um caso diante da Corte de Justiçac ${ }^{16}$.

Na teoria, a obrigação de reenvio exclui o diálogo, que é um momento em que se manifesta, invariavelmente, uma parte de liberdade, própria à troca de argumentos. Mas, obrigar é autoritário; obrigar é compelir. A imperatividade erradica, a priori, o livre arbítrio. Entretanto, mesmo no âmbito dessa figura processual em que nenhum lugar permitia, aparentemente, a discussão, uma troca de opiniões se iniciou entre a instituição, no seio da qual o senhor dedicou uma grande parte de sua carreira, e a Corte de Luxemburgo. Será que eu o aborrecerei se lhe lembrasse que o Conselho de Estado teve muita dificuldade (que eufemismo!) em aceitar as regras do jogo prejudicial? No mesmo tempo (aqui, eu antecipo sua reação que

\footnotetext{
Assinado durante a 34a seção da OUA em Ouagadougou no Burkina-Faso, nos dias 8 e 10 de junho de 1998, entrava em vigor no dia 25 de janeiro de 2004. A Corte foi implantada em Arusha, na Tanzânia, após a eleição de seus onze juizes. Hoje, ela está esperando o tratamento de seus primeiros casos. A literatura sendo abundante, somente relatarei aqui algumas publicações recentes a seu respeito, cf. VAN DER MEI, A. Pieter. The new african court on human and people's rights: towards an effective human rights protection mechanism for Africa? Leiden Journal of International Law, Cambridge, n. 18, p. 113-129, 2005; OUGUERGOUZ, F. La cour africaine des droits de l'homme et des peoples: gros plan sur le premier organe judiciaire africain à vocation universelle. AFDI, p. 213-240, 2006.

${ }^{15}$ Eu lhe concedo que uma das angústias das reviravoltas da integração europeia é o "transformismo" permanente da numeração das disposições dos tratados. Após o artigo 177, T. CEE, foi a vez do artigo $234 \mathrm{~T}$. CE de encarnar o reenvio prejudicial, antes que o artigo 267 T. FUE o fizesse na sua vez, se o segundo "Não" Irlandês da construção comunitária chega a ser ultrapassada para que a ratificação do Tratado de Lisboa, assinado no dia 13 de dezembro de 2007, seja um dia integral. Todavia, visto sua memória, totalmente excepcional, conhecida e louvada por todos, eu garantirei que isso não representa nenhuma dificuldade para o senhor.

${ }^{16}$ A obrigação de reenvio se deslocou para o juiz que não decide em última instância, tratando-se da apreciação de validade; obrigação de origem pretoriana a fim (ainda e sempre) de garantir uma interpretação e uma aplicação uniformes do direito comunitário. Que eu saiba, esta ousadia da Corte de Justiça com a decisão Foto-Frost... não gerou maiores resistências... Daí, nem pensar em diálogo.
} 
imagino ser uma contestação), se não tivesse se tratado de revolta, o diálogo não poderia ter acontecido, pois a obrigação respeitada, a liberdade e o diálogo, portanto, teriam desaparecido. Em outras palavras, a resistência do Conselho de Estado junto à imutável obrigação de reenvio dos tratados abriu uma brecha na obrigação do item 3; a contestação abalou a imperatividade convencional. Então, a discussão podia começar. Ninguém melhor que o senhor conhece os seus rodeios.

Do caso da Sociedade dos petróleos Shell-Berre ao caso Cilfit; em outros termos, da apoteose da "teoria do ato nítido", defendida por Nicole Questiaux ${ }^{17}$ à consagração da margem de apreciação citada por F. Capotorti ${ }^{18}$, os juízes do Palais Royal conseguiram a façanha de conduzir e orientar o que poderíamos chamar - a fim de diversificar os prazeres metafóricos - “a entrevista judicial”. O senhor reconhecerá o fato que os juizes do Planalto de Kirchberg ficaram na "sua escuta" (na escuta do Conselho de Estado, quero dizer), entregando uma interpretação judicial do artigo 234 T. CE, respeitosa de sua posição como daquela do conjunto das jurisdições supremas dos Estados membros. O senhor deve conhecer, sem nenhuma dúvida, a irradiação dessa teoria forjada pelos seus pares nos outros países da União europeia $^{19}$. O trâmite das decisões judiciais e, mais especificamente, aquelas oriundas de sua ilustra instituição, difundiu-se como fogo em rastro de pólvora nos seus colegas europeus, para o melhor e, às vezes para o mais delicado do bom

${ }^{17}$ CE Ass. 19 de junho de 1964, Société des pétroles Shell-Berre et autres, Rec., 344, concl. N. Questiaux. Nicole Questiaux falou também - na perspectiva doutrinal - do significado do extinto artigo 177 T. CE; ela apresentava sua visão das coisas em 1974, cf. A COLABORAÇÃO do juiz administrativo com um juiz internacional: algumas observações sobre a aplicação pelo Conselho de Estado francês do artigo 177 do tratado de Roma. Paris: LGDJ, 1974. Mélanges en l'honneur du professeur Michel Stassinopoulos p. 387-395.

${ }^{18}$ CJCE, 2 outubro de 1982, Cilfit, caso 283/81, Rec., 314, concl. F. Capotorti.

${ }^{19}$ A doutrina estrangeira que analisa o mecanismo prejudicial comunitário faz questão de mencionar a teoria do ato claro; sua apresentação é uma passagem obrigatória da análise da utilização do artigo 234 T. CE. A literatura a esse respeito sendo inúmera, eu lhe recomendo a análise recente de F. Fernandez Segado em SEGADO, F. Fernandez. O controle de 'comunitariedade' da ordem jurídica interna, realizado pelo juiz nacional e suas conseqüências sobre o sistema constitucional. In: Renouveau du droit constitutionne : Mélanges en l'honneur de Louis Favoreu. Paris : Dalloz, 2007, p. 1231-1262, espec. p.1247-1249. 
entendimento jurisdicional com os juízes de Luxemburgo ${ }^{20}$. Nisso, as estatísticas são eloquentes ${ }^{21}$.

As reticências por parte de algumas jurisdições supremas - aqui, lhe garanto que uso a litotes - não deixaram de gerar algumas reações pelo menos paradoxais: o senhor sabia que o legislador sueco tinha vindo ao socorro da Corte de Justiça? Com efeito, ele pedia a toda jurisdição ou autoridade pública que, obrigada em interpor uma ação junto à Corte de Luxemburgo, não o fizesse, teria que justificar sua recusa ${ }^{22}$ ? Quando não é o legislador que replica, é o juiz constitucional que vem acudir o respeito da obrigação do emblemático artigo 234 T. CE que se trans-

${ }^{20}$ A Espanha, pela qual conhece minha preferência cultural, demarcou-se relativamente rapidamente na matéria já que o Tribunal supremo (TS, 15 de março de 1991) se inspirava expressis verbis na teoria do ato claro e isso, bem depois da decisão Cilfit. Mas, para os comentadores espanhóis, a invocação dessa teoria não era pertinente in casu. Eu o remeto à decisão do TS de 15 de março de 1991 e aos comentários de D. Liñan Noguera, M. López Escudero, "Crónica sobre la aplicación judicial del derecho comunitario en España (1991 et 1992)", Revista de Instituciones Europeas, 1994-1 p.257. Não se trata somente de um exemplo dentre muitos outros é claro. A este respeito, a RIE, que se tornou a Revista de Derecho Comunitario Europeo, garante uma crônica regular que indica as resistências ou, ao contrário, as aceitações no que diz respeito ao domínio do direito comunitário europeu sobre o sistema jurídico espanhol. Para a difusão dessa teoria na Áustria, por exemplo, $v$. as decisões VfSlg 14.390/1995, 14.886/1997, 15.106/1998, 15.657/1999, 16.039/2000 mencionadas por H. Schäffer, "Áustria", Cours suprêmes nationales et cours constitutionnelles: concurrence ou collaboration? In memoriam Louis Favoreu, J. Iliopoulos-Strangas (dir.), Ant. N. Sakkoulas, Bruylant, Athènes-Bruylant, 2007, p. 95-123, espec. p. 108.

${ }^{21}$ As instituições judiciais que dão vida ao mecanismo prejudicial são aquelas ditas "inferiores" (que palavra feia) - ou seja, aquelas que não são obrigadas de ativar o reenvio - os supremos tribunais, no seu conjunto, permanecendo, eles, circunspectos no que diz respeito ao "reenvio". Não pense que essa asserção é fruto de um a priori, que no âmbito de um "diálogo científico" seria ainda menos bem acolhida; ela é somente o resultado do conhecimento das preciosas estatísticas fornecidas pela própria Corte de Justiça. No seu Relatório de atividade 2007, podemos descobrir que a Corte de Cassação acionou o mecanismo 76 vezes, o Conselho de Estado 40 vezes, enquanto que as "outras jurisdições" procederam em 627 oportunidades. Longe de mim a ideia de "estigmatizar" as jurisdições francesas. Com efeito, comparando o que pode ser comparado, que dizer um Estado membro que pertencia aos "seis" países fundadores e cuja arquitetura judicial é relativamente similar à do hexágono - constata-se que se trata de uma forte tendência. Dessa forma, na Bélgica, a Corte de Cassação realizou 69 reenvios, o Conselho de Estado 42, enquanto que as chamadas "outras jurisdições" o fizeram 439 vezes. Particularidade do controle de constitucionalidade belga, a Corte de Arbitragem - recentemente renomeada Corte constitucional - usou 5 vezes o artigo 234 T. CE. Para a Itália, os números são: Corte suprema di Cassazione (94); Consiglio di Stato (60); “outras jurisdições" (785).

${ }^{22}$ Lei sueca de $1^{\circ}$ de julho de 2006. 
formou, pelo jogo dos entrelaçamentos sistêmicos, em obrigação constitucional ${ }^{23}$ ! $\mathrm{O}$ que dizer, então, da Corte europeia que integrou a parte também ${ }^{24}$ ? Quando uma obrigação (comunitária) não deixa perceber várias outras (constitucional e convencional), transformando os sistemas jurídicos em sistemas mestiços ${ }^{25}$, dá para medirmos a excepcional transformação das fontes de obediências do juiz doméstico. Todavia, apesar da obrigação que se estreita desdobrando-se; apesar do fato que tudo está feito para que a obrigação - adaptada afinal (Cilfit) - seja respeitada, o diálogo integrado foi, e será ainda marcado por numerosos sobressaltos, pois resiste aos aceitos incondicionados de regras do jogo, julgadas (por alguns juízes e em algumas épocas) demais desestabilizadoras para a ordem jurisdicional interna. Evidentemente, sabe que desde o clássico caso Simmenthal ${ }^{26}$, o diálogo integrado induzido pelo artigo $234 \mathrm{~T}$. CE pode criar interferências com os diálogos prejudiciais de tipo constitucional. Conhece-se também a regra de presença que a Corte de Justiça impôs nas hipóteses de um confronto das obrigações de reenvio. Mas, trinta anos após a solução colocada pela Corte, a paisagem judicial não é nem um pouco uniforme: certas altas jurisdições continuam de se revoltar (que surpresa quando se sabe que elas são oriundas dos "antigos" Estados membros), outras, (mais recentemente integradas no seio do universo comunitário) aceitam o jogo ${ }^{27}$.

${ }^{23} \mathrm{Eu}$ o remeto - o senhor que gosta do direito comparado - às jurisprudências dos Tribunais Constitucionais alemão (Trib. const. 8 de abril de 1987, Kloppenburg), austríaco (Trib. const. 11 de dezembro de 1995; Trib. constit., 26 de junho de 1997) e espanhol (Trib. const., 19 de abril de 2004 ; Trib. const., 19 de junho de 2006) de acordo com as quais o "direito ao juiz" protegido pelas suas respectivas constituições é suscetível de ser burlado se, por acaso, a obrigação do artigo 234 T.CE for desrespeitada.

${ }^{24}$ Sobre o controle, por parte da Corte europeia, do uso do mecanismo prejudicial do artigo 234 T. CE, entrarão aqui algumas referências clássicas, v. CEDH, 23 de março de 1999, Desmots x França (III set., DR) e CEDH, 7 de setembro de 1999, Dotta x Itália (II set., DR).

${ }^{25}$ Aqui, faço uma referência a uma fórmula tomada emprestada a um artigo muito interessante escrito com quatro mãos por N. Levrat E I. Raducu sobre "a mestiçagem jurídica", $v$. «Le métissage des ordres juridiques européens (une «théorie impure » de l'ordre juridique)», Cahiers de droit européen, 2007-1, p.111-147.

${ }^{26}$ CJCE, 9 de março de 1978, Simmenthal, aff. 106/77, Rec., 1978, 629, concl. Reischl.

${ }^{27}$ O Tribunal constitucional alemão (decisão de $1^{\circ}$ de julho de 2006, BvL 4/00) estimou que é impossível estabelecer uma hierarquia entre o artigo 234 T. CE e seu irmão gêmeo constitucional o artigo 100 da Lei Fundamental. Ele remete ao juiz do fundo o cuidado de apreciar a utilidade e oportunidade de tal ou tal outro procedimento no âmbito de um litígio específico. Confrontada a mesma problemática, a Corte Constitucional checa alinhou-se, ela, numa decisão de 21 de fevereiro de 2006, sobre os cânones da jurisprudência Simmenthal. 
São mais elementos para que as discussões judiciais continuem, sobretudo quando se sabe que elas existem, evidentemente, no interior mesmo dos sistemas jurídicos nacionais ${ }^{28}$. A mesma constatação é válida para outra manifestação do diálogo integrado: eu quero falar daquele sempre vivaz, relativo à visão absoluta da primazia definida pela Corte de Justiça, da qual sabemos que ela é bem relativa no tocante às jurisdições nacionais ${ }^{29}$

Hoje (eu lho mencionava um pouco acima), a figura processual do reenvio prejudicial não é mais exclusivamente europeia; ela se "internacionalizou" no sentido em que ela foi importada por outros sistemas de integração. Aliás, eu deveria dizer de preferência que é a União europeia que incentivou a exportação do modelo "de integração" e, consequentemente, os procedimentos judiciais correlatos. Com efeito, a integração se tornou um "valor" em si que a União faz questão de promover e apoiar ad extra ${ }^{30}$. Esse elemento é, em minha opinião, capital. Permitirme-á uma (leve) digressão a esse respeito. A doutrina evidencia sistematicamente - nitidamente, ela tem razão - a santíssima summa divisio entre os sistemas da common law de um lado e do direito continental do outro para decifrar o jogo de influências que os Estados disputam entre si em nível planetário, representando

${ }^{28}$ Certamente, o senhor procurou saber mais a respeito da querela que abalou o pequeno mundo judicial "belga", a Corte de cassação belga recusando interpor uma ação junto à Corte de arbitragem de questões prejudiciais de constitucionalidade. Eu o remeto, nisso, aos trabalhos de M. Verdussen, "Les atouts et les limites du renvoi préjudiciel à la Cour d'arbitrage", La saisine du juge constitutionnel. Aspects de droit comparé, Bruxelles, Bruylant, 1998, p.179 e J. Van Compernolle, M. Verdussen, « La guerre des juges aura-telle lieu? A propos de l'autorité des arrêts préjudiciels de la Cour d'Arbitrage ", JT, 8 de abril de 2000, p.302.

${ }^{29}$ Este diálogo é integrado, pois é co-substancial ao processo de integração; todavia ele não é "institucionalizado" como o procedimento de juiz a juiz do artigo 234 T. CE. Não falta espaço para falar algumas palavras a respeito disso. O assunto é amplamente conhecido; sabe-se que ele é regularmente renovado pela evolução do direito levado em consideração pelos antigos Estados membros (claro, penso aqui, à jurisprudência do Conselho constitucional que, desde 2004, mantém atento o mundo dos constitucionalistas - comunitaristas). A questão é longe de ter sido totalmente explorada, pois os Estados-membros querem, por sua vez, por seus limites constitucionais ao processo de integração.

${ }^{30}$ Basta, para convencê-lo disso (se por acaso tivesse uma dúvida a este respeito), falar da organização na Nicarágua, nos dias 4 e 5 de outubro de 2007, graças ao apoio financeiro e político da União Europeia, do Primeiro Encontro das Cortes Internacionais e regionais de Justiça. Portanto, graças ao Programa PAIRCA - Programa de Apoio a Integração 
esses dois sistemas de direito que refletem, que se queira ou não, duas maneiras de pensar.

Mas, nessa batalha dos "modelos" jurídicos, há um tertium gentium: o direito da integração que se insere nessa concorrência das influências de sistemas. Eu queria precisá-lo, pois, na verdade, poucos estudos se interessaram à realização da descrição desse fato, tão importante quanto à oposição tradicional entre direito anglo-saxão e direito continental ${ }^{31}$. Posto isso, volto ao mecanismo prejudicial. Ele foi previsto em todos os sistemas africanos e latino-americanos de integração, o que confirme - se fosse necessário - que se trata realmente de uma condição processual que é vista como sendo indispensável ao estabelecimento e à viabilidade da criação de um direito integrado ${ }^{32}$. Todavia, previsto nos textos, ainda não entrou totalmente numa mecânica jurisdicional corriqueira. Se funcionarem os sistemas de integração africana e se as jurisdições comunitárias africanas forem efetivas, sua principiante atividade mostra que o mecanismo prejudicial não é (ainda)

Regional Centro-Americana - Programa de Apoyo a la Integración Regional Centroamericana), são os representantes de onze jurisdições internacionais e regionais que puderam trocar suas opiniões, suas diferentes experiências. Aqui, o diálogo não é mais "jurídico”, ele é diplomático. Este tempo da "diplomacia dos juízes" é fundamental. Está totalmente ciente disso, pois o senhor encontra regularmente, no âmbito de encontros institucionalizados (colóquios e outros fóruns), como também e talvez principalmente durante encontros mais informais (almoços surpresas), seus homólogos de todas as especialidades e de todos os países.

${ }^{31}$ O Senhor deve pensar que, aqui, estou esquecendo a citação de uma das numerosas pesquisas da Seção do relatório do Conselho de Estado que tinha salientado, com razão, que não se devia resignar-se a um "cara a cara redutor" entre a common law e o direito romano-germânico. Não esqueço: L'influence internationale du droit français. Etude adoptée par l'Assemblée générale du Conseil d'Etat le 19 juin 2001, Paris, La documentation française, 2001, $159 \mathrm{p}$.

32 Artigo 16 do Tratado de Libreville para a Corte CEEAC; artigo 17 do Tratado de Libreville para a Corte CEMAC; artigo 12 do protocolo adicional $n^{\circ} 1$ ao T.UEMOA; artigos 32 a 36 do protocolo de Cochabamba para a Corte de Justiça da Comunidade andina; artigo $22 \mathrm{k}$. do acordo de Panamá para a Corte centramericana de Justiça; artigo IX (c) do tratado de St Michaël para a Corte de Justiça dos Caribes. 
o procedimento principal ${ }^{33}$, como é na Europa ${ }^{34}$. Aqui, o passar do tempo deve ajudar para que os juízes nacionais se acostumem com o direito integrado e aceitem todas as consequências processuais. Na América Latina, a constatação é diferente, mesmo se houver paradoxos. O sistema de integração mais elaborado - i.e. aquele que funciona melhor no "subcontinente" - é aquele da Comunidade andina. Seu funcionamento judicial favorece recorrer em anulação - que permite um acesso mais fácil por parte dos particulares ao pretório da jurisdição de Quito ${ }^{35}$ - enquanto o reenvio prejudicial conhece um sucesso exemplar ${ }^{36}$ - em que as referências à “jurisprudência mãe” são inúmeras (quero falar aqui da jurisprudência da Corte de Justiça das Comunidades; voltarei nesse ponto mais adiante). Até aqui, nada paradoxal, o universo andino demonstrando que as resistências ao reenvio não são consubstanciais aos sistemas de integração. Na realidade, é imergindo no universo

${ }^{33}$ Eu me permito lhe indicar os trabalhos de S-J. PRISO-ESSAWE que tem no Compêndio Penant uma Crônica sobre a CEMAC e com mais precisão sobre a atividade da Corte de Justiça desta organização que se encontra no Chade, v. "Chronique CEMAC. Chronique des activités de la Cour de justice de la Communauté Economique et Monétaire de l'Afrique Centrale", Penant, 2007, n858, p. 105-125.

${ }^{34}$ As estatísticas não erram. A cada ano, os relatórios da Corte de Justiça fornecem preciosas informações sobre sua atividade em função, principalmente, da repartição dos casos por vias de direito. A palma do êxito vai, sistematicamente (pelo menos desde 2000), ao reenvio prejudicial. Para o ano de 2007, em 580 casos apresentados à Corte - cujo Presidente Skouris destacou o fato que se tratava do número mais alto na história da Corte - 265 o foram pelo viés do reenvio prejudicial, enquanto que 221 tratavam dos recursos diretos no seio dos quais o recurso de constatação de ausente é o principal (212 recursos de ausente contra 9 para anulação) v. Corte de Justiça das Comunidades, Rapport annuel 2007, p.84.

${ }^{35}$ É preciso assinalar ao Senhor que o Presidente da Corte de Justiça da Comunidade andina (Quito), o peruano Ricardo Vigil Toledo, excelente conhecedor dos direitos da integração, gosta de mencionar regularmente que as restrições do acesso dos particulares ao pretório comunitário (europeu) - os famosos limites do item 4 do artigo $230 \mathrm{~T}$. CE confirmados com força pela Corte de Justiça no seu famoso parecer UPA - existem muito pouco em Quito. Ele lembrava o fato durante um seminário de reflexão em Madri em outubro de 2007 sobre o tema "Hacia una Corte suprema Latinoamericana?", v. R. Vigil Toledo, "El aporte del Tribunal de Justicia de la Comunidad andina a la consolidación del bloque regional y la actitud al respecto de los tribunales supremos de los países miembros », Comunicação apresentada em Madri em outubro de 2007 durante o seminário " Hacia una Corte Suprema Latinoamericana?”, ronéo. p.8. Lembro-lhe seu opúsculo Reflexiones en torno a la construcción de la Comunidad Sudamericana de naciones, Quito, Octubre 2006, 177p.

${ }^{36}$ A Corte de Justiça da Comunidade andina (Quito) teve de conhecer, desde 1985, dentre 1407 reenvios prejudiciais, com um pico para o ano de $2005 \mathrm{em}$ que foi acionada com 233 reenvios! Estes dados estatísticos se encontram sobre o site da "comunidade andina" (www.comunidadandina.org). 
do sistema de integração centro-americano ${ }^{37}$ e na atividade da Corte centroamericana de justiça de Manágua (Nicarágua), efetiva desde o dia 12 de outubro de 1994, que se toma a medida dos limites da engenharia institucional. Sobre os sete Estados membros do sistema, somente Salvador, Honduras e Nicarágua ratificaram o Estatuto da Corte de Manágua ${ }^{38}$; todavia, esta estabeleceu (e, portanto, impus) sua competência perante todos os Estados-membros do sistema ${ }^{39}$. Essa jurisprudência construtiva (que lembra o ativismo judicial inicial da Corte de Luxemburgo) era necessária para garantir, simplesmente, a sobrevivência do conjunto sistêmico.

Por um lado, se a Corte de Manágua soube (e apesar de fortes protestações) firmemente garantir sua perenidade e a do sistema, ela não soube impor aos juízes nacionais sua ação na base do artigo/irmão, o artigo/gêmeo, em outras palavras, na base do equivalente centro-americano do artigo $234 \mathrm{~T}$. CE, ou seja, o artigo 22.k do acordo de Panamá ${ }^{40}$. Mas - e aí surgem os limites da engenharia institucional - tudo foi feito para que esta ação seja facilitada. Com efeito, os juízes da Corte

${ }^{37}$ É composto pelos estados seguintes: Costa Rica, El Salvador, Guatemala, Honduras, Nicarágua, Panamá e por adesão, Belize - e se desenvolveu sobre a base do Protocolo de Tegucigalpa (1991) à Carta da Organização dos Estados centro-americanos.

${ }^{38}$ O Estatuto entrava em vigor para os Estados no dia 02 de fevereiro de 1994, conforme interpretação do artigo 48 realizada pelo Conselho judicial centro-americano. Para descobrir as especificidades do sistema, poderá mergulhar na leitura de R. Chamorro Mora, "La Corte Centroamericana de Justicia", Integración Eurolatinoamericana, F. Molina Del Pozo (coord.), Buenos Aires, Ed. Ciudad Argentina, 1996, p. 414.

${ }^{39}$ Corte de Justiça centramericana, 13 de dezembro de 1996, caso ${ }^{\circ} 9$, n 4 -1-12-96, Gaceta oficial de la CCJ, $n^{\circ} 4,22$ de fevereiro de 1997; Corte de Justiça centro-americana, 13 de janeiro de 2005, caso $n^{\circ} 66$, Gaceta oficial de la CCJ, $n^{\circ} 18,1^{\circ}$ de fevereiro de 2005.

40 Adotado na base do Protocolo de Tegucigalpa de 13 de dezembro de 1991, o acordo de Panamá de 12 de dezembro de 1992 é constitutivo do Estatuto da Corte e apresenta de uma maneira detalhada o funcionamento das diferentes vias de direito da Corte de Manágua, que é ao mesmo tempo uma Corte internacional (tanto em matéria contenciosa quanto consultiva), uma Corte de integração, uma Corte arbitral e last but not least uma Corte de apelação. Ele se lê assim. Eu transcrevo o texto em espanhol para que sua leitura aconteça mais perto possível ao texto original: "Resolver toda consulta prejudicial requerida por todo Juiz o Tribunal judicial que estuviere conociendo de un caso pendiente de fallo encaminada a obtener la aplicación o la interpretación uniforme de las normas que conforman el ordenamiento jurídico del sistema." Se, por ventura, a imersão nesse universo integrativo chama sua atenção ao ponto de querer aprofundar a questão, eu me permito, a respeito dessa questão - que demonstra até que ponto os modelos jurisdicionais podem ser ultrapassados - indicar-lhe um estudo que tinha iniciado durante o colóquio de Lille, organizado pela sociedade francesa para o direito internacional, "o fato regional na jurisdicionalização do direito internacional”, Paris, Pedone, 2003, p.203-264. 
centro-americana são diretamente designados pelos juízes das Cortes Supremas dos Estados-membros. Poderia ter se pensado que uma ligação institucional simpática era estabelecida dessa maneira entre os juízes supranacionais e os outros, a fim de evitar a armadilha do afastamento, tanto institucional e sociológico quanto humano. Que engano! Em quatorze anos de atividade, observa-se uma só pergunta prejudicial colocada à Corte de Manágua que não é oriunda de uma Corte Supre$\mathrm{ma}^{41}$. O diálogo não existe; as jurisdições nacionais não o aceitam. Isto coloca, ao extremo limite, a questão da viabilidade de um sistema em que um de seus atores principais não quer "jogar o jogo", demonstrando uma grande indiferença junto às regras sistêmicas. Mas, mesmo no enfrentamento (e talvez, sobretudo, graças a ele), o diálogo é o sinal demonstrando o fato que um sistema jurídico vive. Ignorálo, ao contrário, não será o sinal de uma morte lenta?

\section{0 diálogo convencional}

Quando inaugurou a fórmula de diálogo dos juízes no âmbito do procedimento de "juiz para juiz" do artigo 234 T. CE, hoje a expressão floresce, para não dizer brota em todas as direções no universo convencional europeu ${ }^{42}$. As publicações são muito numerosas: elas mostram, elas só, não o deslocamento das exigências (aquelas do mecanismo prejudicial perduram), mas pelo menos aquele das preocupações ${ }^{43}$. É preciso salientar que a França se "destacou” estes últimos anos nos anais judiciais europeus. As condenações foram difundidas nas mídias, inclu-

\footnotetext{
${ }^{41}$ A pergunta vinha da Primeira Vara do Tribunal Civil de San Salvador em 2006. Essa importante informação é fornecida pelo meu colega argentino Alejandro D. Perotti - grande conhecedor da jurisprudência dos sistemas de integração europeu e latino-americano no seu estudo: "La autoridad de la doctrina de la Corte Centroamericana de Justicia, su aportación a la consolidación del bloque regional y la actitud al respecto de los tribunales Constitucionales/Supremos de los Estados Miembros", Hacia una Corte Suprema latinoamericana?, Madri (para ser publicado no decorrer de 2008).

${ }^{42}$ Terá observado que uso uma metáfora bem fresca e não patológica e isso teria sido o caso se eu tivesse empregado o termo de "proliferação" (frequentemente empregado no universo internacional para mencionar o fenômeno de multiplicação das jurisdições internacionais).

${ }^{43}$ As referências seguintes são certamente familiares. Com efeito, não somente porque não há publicações que escapam a sua atenção, mas também porque o senhor participou de muitas durante colóquios em que juízes e universitários se encontram para "dialogar".
} 
sive do fim do mundo ${ }^{44}$. As constatações de violação que afastaram setores inteiros das áreas do direito francês não diminuíram, enquanto que os questionamentos dos modos de organização da justiça - ancorados nos costumes judiciais de sua instituição como as da Corte de cassação - abalaram os códigos e as certezas, suscitaram a cólera e a reprovação; afinal, incentivaram as resistências. As entrevistas judiciais foram marcadas seja pela discórdia, seja pela concordância. Mas, no contexto sistêmico convencional, na realidade este estado de fato é lógico.

Quero, prezado Presidente, chamar sua atenção neste ponto. Com efeito, eu lhe disse agora há pouco que se houve diálogo no universo integrativo (entre as jurisdições supremas dos Estados-membros e a Corte de Justiça), era excepcional na medida em que, normalmente, a obrigação posta pelo artigo 234, item 3 T. CE não dava nenhuma margem de manobra às jurisdições internas que deveriam ter obedecido sem questionar à obrigação de reenvio. Mas, não é a configuração do sistema convencional. Melhor, como a Convenção não orquestra o diálogo, como as decisões da Corte somente têm um alcance declarativo, a questão é reenviada no domínio das ordens jurídicas internas. Mas, aqui, as generalizações não valem. O mosaico constitucional europeu vai outorgar aparências proteiformas à problemática do diálogo convencional. O Senhor já sabe que alguns mistérios constitucionais implantaram uma orquestração do diálogo dos juízes domésticos com o sistema convencional. Com efeito, como interpretar o artigo $10 \$ 2$ da Constituição

\footnotetext{
A lista seguinte não é exaustiva, pois a literatura é vasta, $v$. F. Lichere, L. Potvin-Solis, A. Raynouard (dir.), Le dialogue entre les juges européens et nationaux : incantation ou réalité ?, Bruxelles, Bruylant, 2004, 242 p. (Col. Droit et justice, n54); B. Lukaszewicz, H. Oberdorff (dir.), Le juge administratif français et l'Europe : le dialogue des juges (Actes du colloque du 50 ème anniversaire des tribunaux administratifs), Grenoble, PUG, 2005, 360 p. ; INSTITUT DE DROIT EUROPEEN DES DROITS DE L'HOMME, Cahiers de l'IDEDH, n¹1, 2007 (mais especificamente a primeira parte sobre o "diálogo dos juizes"). ${ }^{44}$ A decisão de 22 de janeiro de 2008, E.B c. France - que aborda uma questão "universal" (aquela da adoção por homossexuais, especialmente aqui, uma mulher solteira homossexual) - se beneficia de uma "cobertura midiática" impressionante, inclusive até nos países longínquos da América do Sul, como no Uruguai onde a decisão foi comentada tanto no âmbito do jornal televisado da noite, como no jornal mais lido no país, La República. Se o Uruguai ficou na ponta da informação judicial sobre a questão não tem nada de surpreendente. Com efeito, trata-se do primeiro país da América Latina que reconhece o casamento entre duas pessoas do mesmo sexo, graças a uma lei que entrou em vigor em janeiro de $2008 v$. Ley de Unión concubinaria, $\mathbf{n}^{\circ} \mathbf{1 8 . 2 4 6}$. O primeiro casamento civil entre dois homens foi realizado no dia 17 de abril de 2008.
} 
espanhola se não como uma obrigação de integrar o referente convencional entre os parâmetros do controle de constitucionalidade que favorece os direitos fundamentais? Isso explica que, na Espanha, a Alta jurisdição madrilena aplica - apoiada no seu texto constitucional - sem nenhuma má vontade, a jurisprudência da Corte de Estrasburgo; e, portanto, a obrigação é constitucional ${ }^{45}$ ! Em outras palavras, nenhum diálogo que partiria de uma resistência frontal, quase epidérmica à jurisprudência europeia. Inclusive, a literatura espanhola não tem uma efervescência doutrinal sobre o diálogo dos juízes comparável àquela prevalecendo na França ${ }^{46}$; a explicação é simples: as constelações constitucionais não têm nenhum ponto em comum. O que dizer da situação alemã a não ser que ela revela até que ponto nada é estável, que o único elemento de certeza jurídica diz respeito à inconstância judicial? Eis um sistema constitucional que se abriu ao direito da Convenção europeia pela via pretoriana ${ }^{47}$, que mostrou uma empatia judicial totalmente excepcional contra a jurisprudência europeia ${ }^{48}$ e que, de uma vez, volta brutalmente sobre esta

\footnotetext{
${ }^{45}$ Podemos, é claro, questionar para saber, com uma ponta de pérfida ironia, como as coisas teriam evoluído se o artigo $10 \$ 2$ não tivesse existido. De qualquer maneira, para um país como a Espanha, o paradoxo é que a interpretação constitucional da Convenção - quando ela é baseada sobre a jurisprudência da Corte de Estrasburgo - pode assim mesmo, evidentemente, levar constatações de inconvencionalidade. Penso, aqui, por exemplo, à decisão do Tribunal Constitucional de 24 de maio de 2001 (STC n 118/2001). O juiz constitucional emprega a técnica da proteção por tabela a fim de proteger o direito ao meio ambiente, alinhando-se sobre o gabarito colocado pelo parecer López Ostra (Corte EDH, 9 de dezembro de 1994, López Ostra x Espanha). Mas, apesar dessa empatia convencional evidente, foi in fine "recusado" pela Corte no caso Moreno Gómez (Corte EDH, 16 de novembro de 2004, Moreno Gómez x Espanha). O Senhor encontrará uma apresentação mais detalhada desse caso na análise que tinha iniciado durante um colóquio organizado pelo IDEDH da Universidade de Montpellier, "A apreensão constitucional da vida privada. Análise comparativa dos sistemas alemão, francês e espanhol” Le droit à la vie privée au sens de la Convention européenne des droits de l'homme, F. Sudre (dir), Bruxelles, Bruylant, 2005, p. 69-115.

${ }^{46} \mathrm{Na}$ verdade, se "existir tensões ocasionais" entre o Tribunal constitucional espanhol e a Corte europeia - para retomar a expressão do ex-presidente da Alta jurisdição espanhola - elas resultam mais das dificuldades inerentes à articulação entre um sistema internacional de proteção dos direitos humanos e dos sistemas nacionais de proteção dos direitos constitucionais ou fundamentais". Eu o remeto à análise muito interessante de F. Rubio Llorente, "La relation entre les juridictions espagnoles et les juridictions européennes ", Renouveau du droit constitutionnel.., op.cit., p.1387-1410, spéc.1399.

${ }^{47}$ Trib. const. alemão, 26 de março de 1987, Pakelli.

${ }^{48}$ Já que ela simplesmente afastava, para não dizer suprimia, a regra clássica conhecida sob a máxima latina 'lex posterior derogat priorit'.
} 
abertura $^{49}$. Constata-se até que ponto a jurisprudência é marcada pelo fato que é impregnada de acaso e pode variar em função dos sistemas, mas igualmente das épocas e dos juízes ${ }^{50}$

Na França, conhece-se a situação. De um lado, o Conselho constitucional se veste com a Declaração de 1789 e pretende ignorar (na realidade sabemos que ele finge ignorá-la) a Convenção europeia ${ }^{51}$. O conteúdo (oficial) do bloco de constitucionalidade não mudará, apesar de não ter nenhum autor que possa, hoje, negar a influência da jurisprudência da Corte de Estrasburgo sobre as decisões do Conselho constitucional. O diálogo existe, mas ele é limitado pelo fato das características da "aplicação furtiva" 52 da convenção. Do outro lado, o Conselho de Estado e a Corte de Cassação são, como um conjunto das jurisdições administrativas e judiciais do país, os famosos “juízes convencionais de direito comum”. O controle de convencionalidade é deles.

Portanto, aqui, tudo repousa sobre a boa vontade dos juízes ditos "ordinários" (aí também, que expressão infeliz!) e a respeito da boa interpretação que eles fazem, no cotidiano, da Convenção europeia. Em uma palavra, tudo depende

49 Trib. const. alemão, 14 de outubro de 2004, Görgülü. Na falta de espaço para desenvolver a apresentação da argumentação da Corte constitucional alemã, me permito lhe indicar as análises de J. Gerkrath, "O efeito constrangedor das decisões da Corte europeia dos direitos humanos, visto através da perspectiva da Corte constitucional alemã”, RTDH, 2006, p. 706-726; A. Weber, "Dupla ou tripla proteção dos direitos fundamentais na Europa?", Renovação do direito constitucional ..., op.cit., p. 1747-1759.

${ }^{50}$ Qual frustração não pode, neste ponto (como em todos os outros), entrar numa análise mais afinada e, por definição, mais nuançada. Mas, minha "carta aberta" não pode se transformar em "carta aberta super longa"... Afinal, eu penso que a apreciação geral, de acordo com a qual a relação com a jurisprudência convencional europeia depende dos sistemas, das épocas e dos juízes, faz sentido. Para uma análise país por país, o colóquio dedicado à memória de Louis Favoreu constitui uma excelente ferramenta. Sabe-se até que ponto o assunto o interessava, pois na realidade ele estava irritado (pelo menos) pela invasão das jurisprudências europeias e as múltiplas exigências que elas colocavam sobre as Cortes constitucionais $v$. Cours suprêmes nationales et cours européennes? Concurrence ou collaboration? in memoriam Louis Favoreu, J. Iliopoulos-Strangas (dir.), Athènes-Bruxelles, Ant.N. Sakkoulas-Bruylant, 2007, 381p.

${ }^{51} \mathrm{O}$ que seria melhor do que ler a respeito desse assunto as análises de um membro do Conselho Constitucional? O senhor deve conhecer a análise de O. Dutheillet de Lamothe "O Conselho constitucional e o direito europeu", RDFC, 2004, p.30 e seg.

${ }^{52}$ Há alguns anos, num artigo publicado na Revue belge de droit constitutionnel, eu tinha empregado a expressão que devia evocar no leitor a imagem dos "aviões invisíveis": apesar de reais, eles são invisíveis para os radares mais aperfeçoados... 
da lealdade convencional, do compromisso em serem os porta-vozes, no sistema jurídico francês, dos "valores" que a Convenção europeia veicula. Evidentemente, é ai que os problemas começam, pois a interpretação (nacional) da interpretação (europeia) não é uma coisa fácil ${ }^{53}$. Sem voltar na novela judicial relativa ao estatuto do Comissário do governo e do Advogado geral - que foi na França $o$ tema mais emblemático destes últimos anos do "diálogo dos juízes", já que se nutriu de resistências repetitivas e pontos de acordo encontrados afinal - gostaria, aqui, de forma levemente provocadora, interpelar o senhor. Não é ne varietur a interpretação europeia que acaba prevalecendo? Se examinar a questão através da perspectiva da "autoridade de coisa interpretada" ou daquela da "obrigação de disciplina jurisdicional" (para retomar sua expressão) ${ }^{54}$, a jurisprudência europeia não é um tipo de rolo compressor que, afinal, acaba (i.e. ao cabo de um diálogo permeado de muitas tensões) obtendo a adesão dos juízes internos em Estrasburgo? Será o diálogo unicamente uma enganação na medida em que é o argumento europeu que sempre vence? Indagações 'levemente’ provocadoras, eu concordo, mas não se deve ter medo de colocá-las. Na realidade, a situação é sutilmente nuançada, cada um dos dois atores judiciais chegando, afinal, a "tirar vantagem".

${ }^{53} \mathrm{O}$ senhor o enfatizava recentemente durante um dos colóquios anuais do Centro de pesquisa e de estudos sobre os direitos do homem e o direito humanitário (CREDHO) organizado na Universidade de Sceaux. De forma pedagógica, o senhor apresentava as três hipóteses que, em sua opinião, o juiz enfrentava. "Há, primeiro, casos em que as decisões da Corte, por causa da clareza de seu conteúdo e de seu caráter inovador em relação ao direito nacional, conduzem a mudanças profundas. Tem, depois, hipóteses em que as decisões têm uma motivação muito factual e bastante circunstancial. Isso torna difícil qualquer extrapolação e, por isso mesmo, qualquer uso. Enfim, há decisões que são interessantes pelo seu conteúdo, mas cujo pronunciamento intervém num momento em que o direito doméstico já evoluiu. Temos, então, o sentimento de acordo com o qual por mais interessante que sejam em nível do raciocínio jurídico, elas chegam, de certa forma, depois da batalha., La France et la Cour européenne des droits de l'homme. La jurisprudence en 2006, P. Tavernier (dir.) Bruxelles, Bruylant, 2007, p.67.

${ }^{54} \mathrm{O}$ senhor lembrou que o Conselho de Estado não aceitava a teoria "da autoridade de coisa interpretada” que Jean Boulouis inventou (no âmbito comunitário) e Joël Andrianstimbazovina divulgou (no universo convencional). Nessa ocasião, o senhor cita as conclusões dos comissários sob o parecer Subrini (CE, 11 de julho de 1984, D. 1985, p. 150) assim como aquelas apresentadas sob o parecer Bitouzet (CE, 3 de julho de 1998, Rec. 288, concl. Abraham, RFDA 1998, 1243). No entanto, acrescentava imediatamente: "É evidente, no entanto, que a jurisprudência europeia deve ser tomada em conta pelo juiz administrativo. Mas isso atende a um imperativo de disciplina jurisdicional por parte do juiz e não a uma obrigação jurídica ligada à autoridade de coisa julgada ou interpretada." La France et la Cour européenne des droits de l'homme..., op.cit. p.85. 
É preciso admitir que a lógica da garantia coletiva, instituída pelo mecanismo convencional - e devemos sempre lembrar que os Estados a aceitaram de forma soberana - tem como objetivo: estabelecer uma proteção mínima comum a qual todos os Estados partes da Convenção devem se esforçar em aderir para não ver implodir o sistema ${ }^{55}$. Mesmo se considerarmos - com certa dose de provocação irônica - as resistências às decisões Kress ${ }^{56}$ e Marti$n i e^{57}$ como uma perda de tempo e como uma gesticulação judicial reveladora de reflexos institucionais corporativistas (aí, lhe concedo o fato que certa dose de exagero caracteriza minhas palavras) - convirá com o fato que o juiz doméstico sabe também perfeitamente tirar proveito da lógica convencional. Ele não é aquele que, afinal, participa da reforma completa das legislações ultrapassadas e obsoletas? Seu prestígio não sai ganhando com isso? Sobretudo, ele não adere ao que chamamos de doutrina de "interpretação construtiva" ${ }^{58}$ ? Nesse quadro, convirá que ele reassuma incontestavelmente a direção da "entrevista judicial". Principalmente, apesar de a "política jurisprudencial" da Corte europeia ser, efetivamente, marcada nas suas principais linhas pelo uso de uma interpretação teleológica que carrega uma ampliação importante do domínio de aplicabilidade da Convençã $0^{59}$, há o fato que a técnica da margem

${ }^{55}$ G. Cohen-Jonathan, « La fonction quasi-constitutionnelle de la Cour européenne des droits de l'homme ", Renouveau du droit constitutionnel..., op.cit., p.1127-1153. Não deveríamos lembrar também, de forma mais solene, que o sistema foi criado em 1950 para evitar a volta debaixo dos holofotes do palco europeu dos excessos políticos de todos os tipos que tinham desfigurado a Europa, conduzindo-a para o abismo?

${ }^{56}$ Corte EDH, Gde Ch., 7 de junho de 2001, Kress x France.

${ }^{57}$ Corte EDH, Gde Ch., 12 de abril de 2006, Martinie x France.

${ }^{58}$ F. Sudre, "A propósito do 'diálogo dos juizes' e do controle de convencionalidade”, Les dynamiques du droit européen en début de siècle, Paris, Pedone, 2004, p.205-224, espec. p.218. Frédéric Sudre define da maneira seguinte a interpretação construtiva: "O juiz nacional não hesita em realizar uma interpretação construtiva das disposições da Convenção, explorando com dinamismo as potencialidades que lhe oferece o instrumento convencional para o exercício de seu controle de convencionalidade... [Ele pega dois caminhos]. Que o juiz interna proceda a uma interpretação extensiva que o leve além da interpretação europeia, se admitirá então que o juiz nacional prossiga o diálogo com o juiz europeu. Ou que o juiz interno realize uma interpretação inovadora na ausência de uma jurisprudência europeia e convir-se-á, então, que ele inicie um diálogo destinado ao juiz europeu, este tendo que realizá-lo depois."

${ }^{59}$ Edouard Dubout evidenciava este dado no seu estudo "Interprétation téléologique et politique jurisprudentielle de la Cour européenne des droits de l'homme », RTDH, 2008, $\mathrm{n}^{\circ} 74, \mathrm{p} .383-419$. 
nacional de apreciação permite aos juízes nacionais conservarem uma liberdade não negligenciável, sobretudo tratando-se de assuntos particularmente sensíveis ${ }^{60} \ldots$

Na verdade, essa temática em que os direitos fundamentais (pois eles estão, evidentemente, no centro do diálogo) se encontram presos no enlaçamento dos sistemas jurídicos nacionais e convencionais é sistematicamente emaranhada, desviada, desnaturada pelo partidarismo - consciente ou inconsciente, escancarado, ou não - do valor agregado, seja do sistema nacional, seja do sistema internacional. Donde, por sinal ${ }^{61}$ (os obiter dicta sempre me agradaram) a vacuidade da oposição entre o que diz respeito, por um lado, ao descritivo e, do outro, ao prescritivo. A objetividade científica não imporia, ao contrário, reconhecer a impossibilidade de ser completamente, integralmente, irremediavelmente objetivo na análise do direito, dos direitos e dos sistemas aos quais eles são ligados? Recusar a proteção convencional, em nome de uma premissa que se diz metodológica e que, na realidade, é somente um a priori ideológico não vale; igualmente, considerar a priori que ela encarna o máximo da proteção dos direitos também não vale. Esses dois posicionamentos podem facilmente se tornar extremismos, e até integrismos. $\mathrm{O}$ que é, certamente, o que existe, é o emaranhamento das obrigações (que nasceram

${ }^{60}$ Ultimamente, em alguns casos emblemáticos, esta técnica foi mobilizada no estágio da determinação do conteúdo dos direitos e não mais somente no estágio das condições de exercício destes. Este uso, pelo menos iconoclasta da "margem nacional de apreciação" foi vivamente criticado na doutrina quando foi o momento de analisar o caso Vox France. Os autores colocaram este encaminhamento como um "erro" da Corte (ad ex. X. BIOY, "L'arrêt Vo c. France, Une lecture publiciste. Cour EDH, 8 juillet 2004 », RDP, 2005-5, p.1426; F. SUDRE (dir.) «Chronique de jurisprudence de la Cour européenne des droits de l'homme », RDP, 2005-3, p.767). Mas, podemos legitimamente nos perguntar, hoje, na base da confirmação desta abordagem no caso Evans (Corte EDH, Gde Ch., 10 de abril de 2007, Evans x Royaume-Uni, $\$ \$ 54-57)$ se, mais que de um erro ou uma gafe, tratar-se-ia antes de uma "estratégia" voluntária por parte da Corte que se recusaria - nas questões relativas ao "ponto de partida da vida" - em erigir a Convenção em um instrumento de harmonização dos direitos, deixando aos juízes nacionais a liberdade de interpretar como quisessem as legislações internas. Se esta intuição se verificasse, isto significaria que a Corte renunciaria ao fato de ser um instrumento de harmonização dos direitos nessas questões e deixaria ocorrer livremente o mosaico constitucional e legislativo na matéria na Europa.

${ }^{61}$ Os obiter dicta sempre me agradaram se não me fascinaram; sem dúvida, eu abusei nessas linhas de alguns trechos no limite do assunto, mas aí também, a tentação era grande demais. 
e se desenvolveram, a cada vez, em contextos históricos e sociais bem precisos, todos marcados por uma legitimidade igual); é o necessário equilíbrio que os juízes tentam de encontrar através seu diálogo. Com efeito, eles são conscientes que a interpretação dos direitos deve se recortar ao máximo para que a multiplicidade dos sistemas de proteção não esteja na origem de uma cacofonia protetora... "Ordenar o pluralismo" não é hoje o novo ofício dos juízes que não dizem seu nome?

A internacionalização do diálogo dos juízes me obriga (na realidade, é como uma felicidade evidente que realizo o exercício), de abordar a liberação territorial do diálogo convencional e, fazendo isso, lhe entreter alguns instantes da realidade latino-americana. Apesar da lógica induzida pelo sistema convencional americano ser a mesma que a lógica convencional europeia - na medida em que ela se desdobra de um sistema jurisdicional de garantia internacional dos direitos - é verdade que o tempo da implantação do sistema interamericano, assim como aquele de seu fortalecimento não foram, evidentemente, os mesmos nas Américas e na Europa ${ }^{62}$. Inúmeras diferenças envolvem os dois modos de proteção dos direitos. No âmbito do que me interessa aqui, sejam os estigmas do diálogo convencional, pode se afirmar que existem ligações evidentes (que não são "perigosas", ou seja, tranquilas) entre a Corte Interamericana dos direitos humanos e os juízes nacionais. Elas resultaram num "diálogo" - sendo que temos de lembrar aqui que pode assumir tanto a forma da discórdia, quanto a entendimentos frutíferos. $\mathrm{Na}$ realidade, o "comércio judicial” que envolve o juiz de San José e os juízes nacionais resulta de uma dupla série de parâmetros. Por um lado, a Convenção americana impõe (e não induz como na Europa) a adequação dos sistemas legislativos nacionais à norma convencional (artigo 2 da Convenção americana) ${ }^{63}$, enquanto que

${ }^{62}$ O sistema convencional americano nasceu no dia 22 de novembro de 1969 e aconteceu somente dez anos mais tarde, no dia 18 de julho de 1978. A entrada em vigor laboriosa da Convenção americana dos direitos humanos se explica pelo domínio de regimes autoritários sobre as sociedades do Hemisfério Sul naquela época. É com particular entusiasmo que o convido a ler o prólogo que o juiz mexicano Sergio García Ramírez, Presidente da Corte Interamericana dos Direitos Humanos de 2004 a 2007, redigiu como abertura da obra que tive a felicidade de escrever com uma jurista espanhola, A. Úbeda de Torres, Les grandes décisions de la Cour interaméricaine des droits de l'homme, Bruxelles, Bruylant, 2008, p. VII-LXXVIII. Encontrará nela toda a riqueza do universo interamericano dos direitos e a força da doutrina oriunda das Américas.

${ }^{63}$ Lê-se assim: "Si o exercício dos direitos e liberdades visados no artigo 1 ainda não for garantido pelas disposições legislativas ou outras, os Estados partes se comprometem em 
do outro, inúmeros sistemas constitucionais internos não somente atribuem um lugar específico aos tratados de proteção dos direitos, como também incluem a jurisprudência convencional americana entre os parâmetros do controle de convencionalidade ${ }^{64}$. Só tomarei um exemplo que encarna sozinho esses dois elementos emblemáticos do emaranhado dos sistemas, trata-se da Colômbia ${ }^{65}$. Os artigos 93 e 94 da Constituição colombiana de 6 de julho de 1991 estabelecem a superioridade dos tratados relativos aos direitos humanos ratificados pelo Estado assim como as normas de direito internacional humano que, uns e outros não podem ser suspensos, inclusive numa época de estado de exceção ${ }^{66}$. Nesse contexto excepcional de abertura tanto ao direito internacional dos direitos humanitários quanto ao jus in bello, a Corte constitucional colombiana estimou que a jurisprudência da Corte in-

adotar de acordo com suas prescrições constitucionais e as disposições da presente Convenção as medidas legislativas necessárias a fim de efetivar os citados direitos e liberdades."

${ }^{64}$ Indico-lhe alguns grandes nomes da doutrina latino-americana que se debruçaram sobre estes assuntos, $v$. H. Fix-Zamudio, "El derecho internacional de los derechos humanos en las Constituciones latinoamericanas y en la Corte interamericana de Derechos humanos", Revista latinoamericana de Derecho, Año 1, n¹, Enero-Junio de 2004, p. 141-180; E. Jiménez De Arechaga, "La Convención americana de derechos humanos como derecho interno", Boletim da Sociedade Brasileira de Direto Internacional, Brasília, nº69-71, 1987-1989, p. 35-55.

${ }^{65}$ J. Córdoba Triviño, «Aplicación de la jurisprudencia de la Corte interamericana de Derechos Humanos al derecho constitucional colombiano ", Anuario de Derecho Constitucional Latinoamericano, 2007, p. 667-684.

${ }^{66}$ Encontrará em anexo o texto em espanhol a fim que pudesse medir a abertura ao direito internacional da Constituição colombiana: Artigo 93: "Los tratados y convenios internacionales ratificados por el Congreso, que reconocen los derechos humanos y que prohiben su limitación en los estados de excepción, prevalecen en el orden interno. Los derechos y deberes consagrados en esta Carta, se interpretarán de conformidad con los tratados internacionales sobre derechos humanos ratificados por Colombia. El Estado Colombiano puede reconocer la jurisdicción de la Corte Penal Internacional en los términos previstos en el Estatuto de Roma adoptado el 17 de julio de 1998 por la Conferencia de Plenipotenciarios de las Naciones Unidas y, consecuentemente, ratificar este tratado de conformidad con el procedimiento establecido en esta Constitución.

La admisión de un tratamiento diferente en materias sustanciales por parte del Estatuto de Roma con respecto a las garantías contenidas en la Constitución tendrá efectos exclusivamente dentro del ámbito de la materia regulada en él." [Estes dois últimos itens foram acrescentados em conseqüência de uma reforma em 2001 a fim de tomar em conta os imperativos resultando do direito internacional penal]

Artigo 94: "La enunciación de los derechos y garantías contenidos en la Constitución y en los convenios internacionales vigentes, no debe entenderse como negación de otros que, siendo inherentes a la persona humana, no figuren expresamente en ellos." 
teramericana fosse uma referência primordial que se devia levar em consideração na operação de interpretação constitucional ${ }^{67}$. Assim, no campo das violações em massa dos direitos humanos ou, ainda, em matéria de liberdade de expressão, as referências explícitas à jurisprudência interamericana não faltam, enquanto que a doutrina notou que as inspirações implícitas se contavam em não menos de cem $\operatorname{casos}^{68}$. Num contexto deste tipo, o diálogo é somente concordância como também o demonstrou a jurisprudência argentina ${ }^{69}$ ou ainda peruana ${ }^{70}$. Esse dado foi explicitamente incentivado pela própria Corte interamericana em casos históricos recentes que consideram que a lógica do sistema é de induzir um "controle de convencionalidade" diretamente implantado pelo juiz nacional e isso, qualquer que seja seu ofício na arquitetura constitucional - i.e. que o controle de constitucionalidade seja difuso ou concentrado ${ }^{71}$. Inútil dizer que o tempo das resistências não está (ainda?) atuando sobre o continente latino-americano. É inelutável? Podemos afirmá-lo de forma peremptória. Será preciso continuar vigiar a evolução do diálogo convencional no seio das Américas.

${ }^{67}$ Corte constitucional Colombiana, Sentencia C-010/00, mas igualmente sentença C-406/96.

${ }^{68}$ J. Córdoba Triviño, op.cit., p.671.

${ }^{69}$ A sentença da Corte Suprema da Justiça da Nação Argentina de 14 de junho de 2005, Simon Julio Hecto e outros é conhecida de todos os internacionalistas. Os supremos juízes argentinos declaravam nulas as famosas leis ditas de "Punto Final" de 24 de dezembro de 1986 e de "Obediencia Debida" de 4 de junho de 1987 adotadas pelo governo de Raúl Alfonsín com risco de manter vivo o sentimento de injustiça por parte das famílias de desaparecidos. Trechos significativos desta sentença são reproduzidos numa revista publicada com o suporte da Corte interamericana, mas também do Instituto interamericano dos direitos humanos, da Universidade nacional autônoma do México e da Fundação Konrad Adenauer, que leva um nome carregado de símbolos: Diálogo jurisprudencial, $\mathrm{n}^{\circ} 1$, JulioDiciembre 2006, p. 257-273. Para uma visão de conjunto sobre a situação argentina, v. E. S. Petracchi, «Los derechos humanos en la jurisprudencia de la Corte Suprema de Justicia de la República Argentina », Anuario de Derecho Constitucional Latinoamericano, 2006, p. 1253-1278.

70 Tribunal Constitucional do Peru, 29 de novembro de 2005, Santiago Martín Rivas, caso $\mathrm{n}^{\circ}$ 4587-2004-AA/TC.

${ }^{71}$ Corte IDH, 26 de setembro de 2006, Fundo e reparações, Almonacid Arellano e outros x Chile, Série $C n^{\circ} 154, \$ 124$. Eu acho que é inútil aqui de traduzir e reproduzir os trechos chaves deste importante parecer: "A Corte é consciente do fato que os juízes e os tribunais domésticos estejam submetidos ao reino da lei e sejam obrigados, por isso, em aplicar as disposições em vigor na ordem jurídica. Todavia, quando um Estado ratificou um tratado internacional como a Convenção americana, seus juízes, como parte integrante da máquina do Estado, são igualmente submetidos a ele, o que os obriga a zelar para que os efeitos das 


\section{0 diálogo solto}

O diálogo é solto, pois nenhuma obrigação, nenhum sistema jurídico obriga, induz o diálogo. Ele se manifesta fora do jogo sistêmico (tanto integrado quanto convencional). Consequentemente, ele não nasce na resistência às obrigações de um sistema. Nenhuma rédea sistêmica vem dirigi-lo, regulamentá-lo, orientá-lo. Apresentando algumas manifestações emblemáticas do diálogo, ele tem todos os traços da espontaneidade.

Na verdade, o caso é mais complexo. Podemos, legitimamente, nos questionar para saber se a crônica do diálogo solto não seria, na realidade, aquela de um diálogo amplamente anunciado. O juiz que dialoga assim com outros juízes, sem nenhuma obrigação para fazê-lo, encontra-se, na realidade, inserido numa rede de vinculações mais ou menos exigentes. Como a teoria de "mão invisível” de Adam Smith, um conjunto de vinculações judiciais invisíveis leva os juízes a dialogar, a citar "jurisprudências oriundas de outro lugar", aquelas se localizando fora de seu próprio sistema de referência ${ }^{72}$. Conseguindo decifrar o círculo das obrigações, o sentido do diálogo aparece então; seria melhor se eu dissesse os sentidos.

disposições convencionais não sejam desviados pela aplicação de leis contrárias a seu objeto e seu objetivo e que, desde o início, são desprovidas de efeitos jurídicos. Em outras palavras, $o$ poder judicial deve exercer um tipo de "controle de convencionalidade" entre as normas jurídicas internas que eles aplicam em casos concretos e a Convenção americana dos direitos humanos. No âmbito desta função, o poder judicial deve levar em consideração não somente o tratado, como também a interpretação que a Corte interamericana fez dele, esta sendo o último intérprete da Convenção americana. Este trecho deixa entender que o juiz doméstico tem o poder de resolver um conflito entre uma lei interna e uma disposição da Convenção americana em proveito desta última. Sobretudo, ele convida o juiz doméstico a se prender tanto ao texto da Convenção como evidentemente à interpretação dada pela Corte, o que supõe que ele seja atento à evolução jurisprudencial interamericana. Algumas precisões complementares foram trazidas a respeito deste controle no caso dos Trabalhadores licenciados do Congresso. Podemos ler que "os organismos do poder judicial devem exercer tanto um controle de constitucionalidade quanto um controle de convencionalidade ex officio" e que deve se efetuar "no âmbito das competências e das regras processuais correspondentes": Corte IDH, 24 de novembro de 2006, Fundo e reparações, Trabalhadores licenciados do Congresso (Aguado Alfaro e outros) x. Peru, Série ${ }^{\circ} 158, \$ 128$.

${ }^{72}$ Aqui, não pretendo fazer uma distinção que rompe entre os juízes domésticos e os juízes internacionais e seu uso respectivo tanto do direito interno "estrangeiro" (foreign law) quanto do direito internacional como tal. Alguns autores (notadamente constitucionalistas) não coloquam no mesmo nível o uso das decisões de justiças internas "estrangeiras" e as decisões internacionais. Aqui, penso no artigo muito interessante de S. Sanders « Judicial dialogue in common law countries », Renouveau du droit constitutionnel..., op.cit., Paris, Dalloz, 2007, p. 413-428. 


\section{As manifestações do diálogo}

Eu não vou, aqui, nesta homenagem epistolaria, apresentar o florilégio dos diversos tipos jurisdicionais que atuam pelo mundo afora. Fora de cogitação ver sua atenção falhar por uma apresentação que tomaria rapidamente a aparência de uma litania desagradável. Meu propósito consiste mais simplesmente em revelarlhe as manifestações as mais vivas deste diálogo solto que se instalou tanto de forma horizontal quanto de forma vertical no interior dos continentes, mas também entre suas margens. Essas imagens geométricas estão aí somente para melhor visualizar um fenômeno de uma riqueza totalmente excepcional; não veja ali, algum julgamento de valor sobre a igualdade ou ao contrário, a hierarquia entre as jurisdições. A configuração das relações entre os direitos, os sistemas e os juízes não é mais marcada por tais apreciações invalidadas, hoje, por uma complexa realidade jurisdicional. Hoje, o entrelaçamento é a palavra chave; a "rede", para não citá-la, irradia as teorias contemporâneas do direito ${ }^{73}$. Aliás, o Conselho de Estado, através das conclusões de um jovem de seus membros no, doravante, histórico caso Arcelor, não apontava esta abertura às teorias que eu me adianto a nomear "as teorias da abertura", atribuindo às teses "Delmas-Martianas" ${ }^{74}$ do "pluralismo ordenado" um lugar de destaque ${ }^{75}$ ? Visitemos juntos, se quiser, o que poderia parecer, de início, como um diálogo horizontal espontâneo. É atravessado por uma summa divisio bastante clássica. A horizontalidade nacional caracteriza um diálogo entre juízes

${ }^{73}$ A obra de F. Ost e de F. De Kerchove, De la pyramide au réseau? Pour une théorie dialectique du droit, Bruxelles, Publicação das Facultés universitaires Saint-Louis, 2002, 596 p. é hoje um "clássico"; um sinal evidente sobre as mudanças profundas que permeiam o direito e, consequentemente, os estudos sobre o direito. Prova disso, a reativação da reflexão que diz respeito às teorias sobre o pluralismo jurídico, v. a este respeito L. Fontaine (dir), Droit et pluralisme, Bruxelles, Bruylant, 2007, 398 p.

${ }^{74}$ A fórmula é regularmente empregada (com empatia) por aqueles que acompanham com entusiasmo as reflexões de M. Delmas-Marty, grande jurista da "abertura", do "deslocamento dos olhares" cujos trabalhos demonstram que a passagem das fronteiras tanto entre os ramos do direito quanto entre as disciplinas é tão desejável como possível. Sua trilogia a respeito das "forças imaginantes do direito" renova, de forma sem igual, a reflexão sobre a maneira de apreender hoje o estudo do direito, Le relatif et l'universel, Le pluralisme ordonné, La refondation des pouvoirs. Todas estas obras foram publicadas pelo Seuil (2004, 2006 e 2007).

${ }^{75}$ Conclusões do Comissário do governo Mattias Guyomar no caso julgado pelo Conselho de Estado no dia 8 de fevereiro de 2007, Arcelor Atlantique e Lorraine e outros, req. 287110 . 
nacionais de países diferentes, enquanto que a horizontalidade internacional, é ela a manifestação do diálogo intenso entre as numerosas e diversificadas jurisdições internacionais. Citar decisões nacionais "estrangeiras” é, hoje, algo corriqueiro para juízes constitucionais e supremos; a "fabricação" das decisões de justiça é apanhada pelo direito comparativo e se repercuta, automaticamente, na rapidez como tal das decisões de justiça. Os exemplos são numerosos; os meios modernos de comunicação eletrônica, os bancos de dados na tela são instrumentos preciosos para descobrir estas “entrevistas judiciais”. Muitas decisões mostram que a Europa, por exemplo, é irremediavelmente colocada em rede judicial. Assim, no âmbito do que constitui a "pequena história” da implantação da ordem de prisão europeia, é preciso notar a inacreditável abertura às decisões oriundas, aliás, do parecer Constantinou da Corte suprema cipriota ${ }^{76}$. E cita as decisões das Cortes constitucionais alemã, grega e polonesa sobre a ordem de prisão europeia ${ }^{77}$. O que dizer também da abertura das jurisdições de common law à jurisprudência de outras jurisdições nacionais? A Corte Constitucional da África do Sul, a Corte Suprema da Austrália, a Corte Suprema do Canadá ou ainda a Corte de Apelação de Hong-Kong não hesitam a se referir a uma jurisprudência nacional estrangeira para o seu sistema nacional de referência ${ }^{78}$. Quanto à horizontalidade internacional, eu não o surpreenderei lhe dizendo que ela é proteiforma e bastante variada. Ela pode se materializar entre Cortes assentadas num mesmo continente, apesar das diferenças de estatuto e de ofício entre os juízes. É a mesma coisa com o diálogo entre a Corte europeia dos direitos humanos e a Corte de justiça das Comunidades europeias, suficientemente conhecidas para que eu não insista nele. O que dizer das “entrevistas" entre a

${ }^{76}$ Corte suprema da República de Chipre, 7 de novembro de 2005, Advogado Geral c. Costa Constantinou, n²94/2005.

77 Trib. const. Alemão, 18 de julho de 2005, 2BvR 2236/04, Deutsches Verwaltungsblatt 2005, p. 1119-1128; Corte de cassação grega, 20 de dezembro de 2005, $\mathrm{n}^{\circ} 2483 / 2005$; Tribunal constitucional polonês, 27 de abril de 2005, P 1/05, Dziennik Ustaw 2005.77.680.

${ }^{78}$ Corte constitucional da África do Sul, State v. Makwanyane, n³/94; Corte suprema da Austrália, Australian Capital Television Pty Ltd v. Commonwealth (1992), 177 CLR 106; Corte suprema do Canadá, Soulos v. Korkontzilas, 146 DLR (4th); Corte de apelação de Hong Kong, Leung Kwok Hung v. Hong Kong Special Administrative Region, 8 de julho de 2005. Estas diferentes decisões são citadas in S. Sanders « Judicial dialogue in common law countries ", Renovação do direito constitucional..., op.cit., Paris, Dalloz, 2007, p. 413-428. 
Corte europeia dos direitos humanos e as jurisdições internacionais penais ${ }^{79}$ entre a Corte de Justiça e o "embrião de jurisdição" relativa à Organização Mundial do Comércio $^{80}$; entre a Corte de Justiça, a Corte AELE e o Tribunal Internacional do Direito do Mar $^{81}$. Esse diálogo se materializa igualmente além das fronteiras continentais, atravessando os oceanos. O que dizer do diálogo entre a Interamericana dos direitos humanos e a Corte europeia ${ }^{82}$ ? Entre a Corte de Quito ${ }^{83}$ ou, ainda, de Ouagadougou ${ }^{84}$ e a Corte de Luxemburgo?

${ }^{79}$ São múltiplos, pois evidentemente os dois juízes são levados, ao grado de sua aprehensão respectiva, a dever levar em conta, seja o direito humano e, portanto, a jurisprudência europeia para alguns (ad ex. TPIY, 22 outubro de 1997, Mrskic, Dokmanovic e outro; TPIY, 04 de setembro de 1998, Delalic), seja o direito internacional e mais especificamente a jurisprudência internacional penal para o outro (Corte EDH, 21 de novembro de 2001, Al-Adsani x Royaume-Uni; Corte EDH, 4 de dezembro de 2003, MC x Bulgarie). Estas instâncias judiciais são também naturalmente conduzidas a levar em conta questões ligadas à doutrina do lis pendens. Neste último ponto, eu o remeto ao raciocínio da Corte europeia no caso Bankovic (Corte EDH, 12 de dezembro de 2001, Bankovic e outros) relativo aos procedimentos paralelos diante da CIJ e do TPIY.

${ }^{80} \mathrm{Eu}$ o remeto aqui, não a referências jurisprudenciais, mas a um estudo que avalia bem a questão sob o ângulo particular das relações de sistemas e que lhe permitirá medir o "estado" do diálogo entre as duas jurisdições, A. Laget-Annamayer, "Le Statut des accords OMC dans l'ordre juridique communautaire: en attendant la consécration de l'invocabilité", RTDE, 2006, p. 249-288.

${ }^{81}$ CJCE, 30 de maio de 2006, Comissão x Irlanda, C-459/03, rec. I-4635.

${ }^{82}$ Os trabalhos comparativos sobre os dois sistemas efetivos de proteção dos direitos são, muitas vezes, fruto de ex-presidentes da Corte de San José. Para alguns exemplos, citaremos o trabalho do uruguaio Hector Gros Espiell, "Le système interaméricain comme régime régional de protection des droits de l'homme", Recueil des Cours de l'Académie de droit international de La Haye, 1975, T. 145, n 2, p. 7-55; "La Cour interaméricaine et la Cour européenne des droits de l'homme", Liber Amicorum Marc-André Eissen, Bruxelles, Bruylant, 1995, p. 233-246 ; do Brasileiro Antonio Cançado Trindade, "The Development of International Human Rights Law by the Operation and the Case-Law of the European and the Inter-American Courts of Human Rights", Human Rights Law Journal, 2004, Vol. 25, n 5-8, p. 157 ou ainda evidentemente do Americano Thomas Buergenthal, "The European and Inter-American Human Rights Courts: Beneficial Interaction", Protection des droits de l'homme : la dimension européenne, Mélanges en l'honneur de Rolv Ryssdal, P. Mahoney, F. Matscher, H. Petzold (eds.), Köln/Berlin/Bönn/ München, Carl Heymans, 2000, p. 123-133.

${ }^{83}$ Ad ex. Corte de Justiça da Comunidade Andina, parecer 3, AI, 96.

${ }^{84}$ Ver as conclusões do juiz relator Mbacké no caso julgado pela Corte de Justiça da União econômica do Oeste Africano, 29 de maio de 1998, Laubhouet Serge x Commissão de l'UEMOA de 29 de maio de 1998, Recueil de la Jurisprudence de la Cour de l'UEMOA (01-2002), Ouagadougou, Burkina-Faso, p. 21-41. 
Listar as manifestações nacionais e internacionais deste diálogo horizontal solto seria sem fim, da mesma forma que as manifestações do diálogo vertical que se instauram entre as jurisdições nacionais e internacionais quando nenhum sistema (integrado e/ou convencional) as obriga a manter tais “conversas". Quando a Corte Suprema da África do Sul ou ainda, fato excepcional, quando a Corte Suprema dos Estados Unidos ${ }^{85}$ adota a jurisprudência da Corte europeia, o fato é notado e notável. Quando, na sua vez, a Corte de Estrasburgo namora as jurisprudências da Corte Suprema do Canadá, da Austrália ou da África do Sul, não se pode passar ao lado de tal circulação das decisões de justiçą ${ }^{86}$. Na verdade, surgem - imponentes e irresistíveis - os limites de tal recenseamento desprovido de análises críticas explicativas. Pois, enfim, uma vez o fato constatado, os questionamentos se chocam. Sobretudo, podemos generalizar, podemos ignorar cada contexto, cada delimitação do ofício do juiz, de cada estigma dos ordenamentos (nacionais e internacionais), que são fatores que podem explicar o uso de decisões de justiça "exógenas" aos sistemas de referência? Igualmente, será que não é um pouco demais simplista falar de abertura às decisões de justiça sem avaliar as diferenças nos modos de citação e, portanto, seu uso concreto? Uma referência ao título dos "fatos", evidentemente, não tem o mesmo valor que um lugar privilegiado no seio da argumentação do juiz como tal. Da mesma forma, o uso das decisões estrangeiras por um juiz dissidente não tem nem o mesmo alcance, nem o mesmo significado que um uso pelo colégio dos juízes. Será que não é um pouco redutor falar em "diálogo" quando, na verdade, poderíamos ver nele somente um uso bem clássico do direito comparado? Estou ciente que as dificuldades metodológicas são inúmeras no momento de abordar tais questionamentos, que se desdobram ao infinito. As-

\footnotetext{
${ }^{85}$ Corte Suprema dos Estados-Unidos, 26 de junho de 2003, Lawrence v. Texas [539 US, 2003]. Esta decisão deu a volta ao mundo das crônicas judiciais. A Corte deu, com efeito, uma reviravolta espetacular em relação à decisão Bowers v. Hardwick [478 US, 1986] finalizando a repressão penal da sodomia. Além da decisão, no fundo, foi a forma de mudar de direção que foi notada. A decisão Dudgeon x Irlanda de 22 de outubro de 1981 tendo estado no centro da motivação do juiz supremo e isso não foi feito sem oposições internas, notadamente oriundas, entretanto, do Chief justice Rehnquist (Presidente) e dos juízes Thomas e Scalia.

${ }^{86}$ J. F. Flauss, «Du droit international comparé des droits de l'homme dans la jurisprudence de la Cour européenne des droits de l'homme», Le rôle du droit comparé dans l'avènement du droit européen, Lausanne, 14-15 de abril de 2000, Zürich, Schulthess, Publications de l'Institut suisse de droit comparé, 2002, p. 159-182.
} 
sim, é possível apresentar explicações válidas enquanto que a cartografia precisa e acabada dos diálogos judiciais através do mundo é um exercício louco, impossível de implantar, salvo se dispuser de um batalhão de comparatistas e de ferramentas inteligentes de pesquisa informática, e mesmo assim... As decisões de justiça que circulam e que acedem à notoriedade judicial mundial não são, com efeito, somente a face emergida de "um iceberg judicial" tentacular e, finalmente, insondável?

Apesar desses numerosos obstáculos, aspiro, mesmo assim, (muitas vezes, é preciso ser levemente inconsciente para avançar) a notar e encontrar os dados objetivos que explicam a abertura às jurisprudências "exógenas". Em outras palavras, por que tal empatia judicial? Poderia replicar imediatamente através de outra interrogação que permita lhe fornecer uma parte da resposta. Por que, enquanto todos os setores das sociedades são engolidos pela globalização, por que imaginar que os mundos judiciais ficariam afastados? Trata-se, antes de tudo, de um sinal dos tempos modernos marcados pelo espírito de certo "cosmopolitismo". Um sinal particularmente sadio, se eu puder acrescentar. Os juízes não permanecem enclausurados nas suas torres enquanto que, por toda parte, a necessidade de se adaptar à interpretação dos mercados, das economias, das finanças, da pesquisa etc. impera. Os questionamentos se tornam idênticos de perto ou de longe nos cinco continentes, principalmente quando se trata de direitos fundamentais. Os juízes não podiam simplesmente ficar na beira da estrada, i.e. fora das múltiplas mutações dos sistemas jurídicos e de suas interconexões; não podiam ser espectadores desse movimento sem ter a vontade (bem compreensível) de se tornar atores principais dele, sob pena de ver sua autoridade e, sem dúvida, igualmente, sua legitimidade (suficientemente discutida de vez em quando) claramente questionadas. Nesse contexto de abertura dos sistemas, não é de se admirar do fato que os atores que os compõem sejam atentos a o que acontece "em outro lugar", o que acaba aparecendo na função de julgar. Dessa forma, os advogados das partes ${ }^{87}$ como os amici curiae (quando os procedimentos, nacionais ou internacionais permitem

\footnotetext{
${ }^{87}$ Este ponto é evocado da análise de S. Saunders, «Judicial dialogue in common law countries», Renouveau du droit constitutionnel..., op.cit., Paris, Dalloz, 2007, p. 413-428. Ver também, G. Canivet, "Les influences croisées entre juridictions nationales et internationales. Eloge de la 'bénévolance' des juges », Revue des Sciences criminelles, Outubro-dezembro de 2005, p. 805-806: "os advogados são também poderosos vetores de influência. São eles que, pelas referências que eles invocam e as citações que eles fazem das jurisprudências externas, estabelecem concordâncias entre as cortes internacionais ou nacionais."
} 
sua intervenção) $)^{88}$, os "defensores objetivos do direito" (para citar uma figura que conhece bem) são atores que levam logicamente ao conhecimento dos juízes a existência de decisões judiciais "exógenas" ao sistema de referência. Essa abertura às decisões de justiça “externas” revela-se mais necessária pelo fato dos juízes serem, na realidade, colocados em concorrência. Esta última não aperta o mercado; ela irradia também o direito. A "luta pelo direito" é uma luta sem trégua em que é preciso poder ser ouvido e impor sua "cultura jurídica”. A doutrina analisou esse dado sob a perspectiva da batalha dos modelos entre common law e direito continental (já falei a respeito mais acima) ${ }^{89}$. Todavia, no universo da aparente espontaneidade do diálogo dos juízes, há outros fatores do que essa luta dos modelos, que explicam que os juízes se abrem aos outros juízes. Da apresentação desses fatores eu chego, irremediavelmente, ao questionamento do significado do diálogo.

\section{Os sentidos do diálogo}

Entregando-lhe, nas linhas a seguir, os dois sentidos do diálogo que me aparecerem como sendo o resultado de tendências de fundo, estou ciente que com uma apresentação binária dessa eu corro o risco de simplificar as coisas ao máximo e passar ao lado da "complexidade" do real. O "paradigma da simplificação" denunciado por Edgar Morin, é, infelizmente, uma armadilha na qual podemos facilmente cair, o pensamento cartesiano sendo irremediavelmente ligado ao Ocidente, para não dizer à França ${ }^{91}$. Tentarei escapar disso destacando, tanto quanto necessário, as contradições, as tensões, os impasses do diálogo. Se “a complexidade

\footnotetext{
${ }^{88}$ Aquele que foi Primeiro presidente da Corte de Cassação (e que doravante atua no Palais Montpensier) pôde escrever assim: "há vários anos que a Corte de cassação está à procura de procedimentos que permitam, diante dela, a expressão dos interesses gerais interessados pelas questões debatidas no âmbito dos pedidos que lhe são endereçados [...]. Tratase de pedir explicações a respeito de um fato comum a toda uma série de litígios e cuja boa apreciação é necessária para forjar, na ausência de qualquer lei sobre este ponto, a regra de direito adequada", G. Canivet, "L'amicus curiae en France et aux Etats-Unis", Revue de jurisprudence commerciale, março-abril de 2005, n², p.99 e 106.

${ }^{89}$ J. Allard, A. Garapon, Les juges dans la mondialisation, Paris, Seuil, 2005, p.; G. Canivet, "Les influences croisées entre juridictions nationales et internationales. Eloge de la 'bénévolance' des juges", Revue des Sciences criminelles, outubro-dezembro de 2005, p. 805-806.

${ }^{90}$ E. Morin, Introduction à la pensée complexe, Paris, Seuil, 2005, p.18 (Col. Points Essais).

${ }^{91}$ E. Morin escreve assim que "vivemos sob o domínio dos princípios de disjunção, de redução e de abstração cujo conjunto constitui o que eu chamo "o paradigma da simplificação".
} 
apresentar-se sob os traços preocupantes da confusão, do inextricável, da desordem, da ambiguidade, da incerteza“" ${ }^{92}$, tentarei não desestabilizar-me com isso. Além da complexidade do real, parece, entretanto, que o diálogo destaca um ideal (ora reivindicado, ora induzido) de coerência. Trata-se, ora de garantir a coerência de sistemas cujos princípios de funcionamento são similares: encontramos, então, aqui, a lógica de sistema, é o ideal sistêmico; ora in fine de fazer prevalecer uma visão comum dos direitos da pessoa humana, e até de seu grau de proteção, é o ideal humanista. O ideal sistêmico é evidente no campo dos processos de integração (econômica e política); induzem necessariamente a um diálogo entre os juízes dos sistemas integrativos. Alguns exemplos serão suficientes, acho, para convencê-lo. Vamos observar um momento as razões que explicam que a Corte AELE faça uma referência às decisões da Corte de justiça das Comunidades europeias ${ }^{93}$. Estará de acordo comigo para dizer que, aqui, nenhum procedimento institucionalizado obriga ao diálogo e que nenhuma luta para uma "cultura jurídica” específica está presente. Na verdade, as referências são induzidas pelas obrigações decorrentes da existência dos sistemas do Espaço econômico europeu de um lado e da União Europeia do outro e cujos princípios de funcionamento têm que ser interpretados da forma mais compatível possível entre si para não criar desordem, incerteza, para não dizer insegurança jurídica ${ }^{94}$. A coerência é vital para a efetividade dos sistemas AELE e UE e se revela ser explicativa do diálogo. Na realidade, encontramos esta necessidade de coerência vital no diálogo dos juízes nacionais - ligados ao sistema de integração europeia- quando eles devem implantar a decisão-quadro da ordem

Descartes formulou este paradigma mestre do Ocidente, disjuntando o sujeito pensante (eco cogitans) e a coisa entendida (res extensa), quer dizer filosofia e ciência, e colocando como princípio de verdade as ideias "claras e distintas", seja o próprio pensamento disjuntivo. Esse paradigma que controla a aventura do pensamento ocidental desde o século XVII permitiu certamente os grandes progressos do conhecimento científico e da reflexão filosófico; suas últimas conseqüências nocivas somente se revelaram no século XX.”, Ibid., p.18.

92 Ibid., p.21.

${ }^{93}$ Como exemplo recente, ver Corte AELE/EFTA Court, 30 de outubro de 2007, Efta Surveillance Authority / The Kingdom of Norway, E 2/07.

${ }^{94}$ Leiamos um especialista destas duas Cortes: "The relationship between the interpretation of EC and EEA principles, wich are in many respects identical to EC law, the EFTA Court is obliged to fllow ECJ precedents from before 1992, and to take later ECJ judgments duly account. In the other hand, the ECJ is not obliged to take account of judgements of the EFTA Courts. Yet, as the ECJ's President has stated, ignoring EFTA Court precedent would simply be incompatible with the overriding objective of the EEA agreement, wich is homogeneity.", 
de prisão europeia... Quando nós nos debruçamos sobre a circulação das decisões de justiça entre os sistemas de integração europeia, africana e latino-americana, a constatação é reveladora da complexidade de decifrar o sentido da circulação das decisões de justiça. Com efeito, se o ideal de coerência for presente, ele não tem o mesmo significado que no universo europeu. Ele é vital, com certeza, mas não da mesma maneira. Explico.

Na realidade, não se trata, aqui, de "diálogo" no sentido no qual foi definido no âmbito das minhas palavras introdutórias. Não há, propriamente dito, uma discussão "a dois ou mais". A unilateralidade se impõe no lugar da troca. Com efeito, as Cortes de Quito, de Manágua ou ainda de Ouagadougou, são tantas jurisdições reguladoras da edificação dos Mercados comuns andino, centro-americano e do oeste africano se referem, sistematicamente, às decisões da Corte de Justiça das Comunidades europeias nas suas decisões ${ }^{95}$, mas o contrário, simplesmente não existe. A Corte de Luxemburgo ignora literalmente essas jurisprudências, mesmo se a União Europeia, de forma mais ampla, não ignora estes “jovens” sistemas de integração.

A explicação da referência à jurisprudência dos juízes do Planalto de Kirchberg encontra-se nem na obrigação (nós não encontraremos nenhum vestígio de obrigação nos tratados constitutivos das organizações africanas e latino-americanas), nem numa manifestação qualquer de uma estratégia concorrencial em que se trataria de impor uma "cultura jurídica". Na realidade, somente vale a necessidade de dar peso a uma jurisprudência principiante recobrindo-a com uma autoridade sem contestação, pois histórica: aquela da "jurisdição-mãe" que foi aquela que participou da construção do sistema de integração europeia. O sentido do diálogo

\footnotetext{
M. Bronckers, "The relationship of the EC Courts with other International Tribunals: noncommittal, respectful ou submissive ?", Common Market Law Review, 2007, p. 601-627, esp. p.605. A referência às palavras do presidente Skouris é a seguinte: V. Skouris, "The ECJ and the EFTA Court under the EEA Agreement : A pardigm fot international cooperation between judicial institutions", Baudenbacher, Tresselt, Orlygson (Eds), The EFTA Court : Ten years on, Oxford and Portland, 2005, p.123.

${ }^{95}$ Faltando espaço, me autorizo remeter-lhe a um estudo que tinha realizado em homenagem a um colega que teve a felicidade de trabalhar durante vários anos junto ao Presidente poeta Léopold Sedar Senghor, "Levar a sério os direitos comunitários. A força da atração da experiência europeia na África e na América Latina”. Les dynamiques du droit européen en début de siècle. Etudes en l'honneur du Professeur Jean-Claude Gautron, Paris, Pedone, 2004, p.563-580.
} 
(do qual vimos que não é um diálogo no sentido exato da palavra...); o sentido da importação da jurisprudência comunitária europeia (é mais correto) reveste aqui as vestes da legitimação. Feito isso, a consequência de tais referências é, afinal, a consagração de uma coerência sistêmica intercontinental que valoriza a especificidade das organizações de integração. Podemos até afirmar que, a contrario, é nisso que resulta a recente referência à jurisprudência fundadora Costa $x$ Enel por Wilfrido Fernández, que foi presidente do Tribunal Permanente de Revisão (TPR) do MERCOSUL. Na ocasião da primeira "decisão consultiva" deste Tribunal, cuja sede encontra-se em Asunción, no Paraguai ${ }^{96}$, o Presidente - que foi posto em minoria in fine... - aproveitou, assim mesmo, da oportunidade para expor sua concepção do mecanismo prejudicial existente no seio do sistema do MERCOSUL, para que acabe se aparentando completamente ao artigo 234 T. CE... $)^{97}$. E envolveu-se numa vibrante defesa do reconhecimento da especificidade do direito da integração, criador de uma "ordem pública regional". O ideal sistêmico se manifesta igualmente quando um juiz se preocupa em preservar a unidade de uma ordem jurídica na qual ele se insere.

Penso, aqui, na jurisprudência da Corte europeia que, porque ela é irremediavelmente ligada ao direito das organizações internacionais, porque ela não pode se subtrair totalmente às regras do direito internacional público (como, por exemplo, o direito dos tratados), não pode não levar em conta a ordem jurídica internacional. Encontremos, então, a realidade legitimadora quando a Corte de Estrasburgo toma o cuidado de mencionar decisões de sua colega que reinou muito tempo sozinha sobre o universo judicial internacional: a Corte internacional de justiça para não citá-la ${ }^{98}$. A preocupação da legitimação não é, evidentemente, a

96 Tribunal Permanente de Revisão (TPR), decisão consultiva de 3 de abril de 2007, nº 1/2007 (www.mercosur.int).

${ }^{97}$ O procedimento da "opinión consultiva" é uma figura processual "híbrida”. Se ela se inspirou no reenvio prejudicial do artigo $234 \mathrm{~T}$. CE, todavia, dele não adota toda a lógica, já que a decisão do TPR não interrelaciona as jurisdições nacionais. Este ponto pode imaginar, faz surgir vivas controversas doutrinais no seio das Américas, ver entre uma abundante literatura, R. Ruiz Diaz Labrano, "Las opiniones consultivas ante el Tribunal Permanente de Revisión del Mercosur a través de los tribunales superiores de los Estados partes", Anuario de Derecho Constitucional Latinoamericano, 2006, p. 629-651.

${ }^{98}$ Estes últimos anos é o caso Mamatkulov e Askarov x Turquia - que resultou em duas decisões - que chamou a atenção dos comentaristas, na medida em que a Corte de Estrasburgo manifesta uma abertura excepcional para com a jurisprudência da CIJ (Corte 
mesma que aquela evocada anteriormente para as Cortes africana e latino-americana. Trata-se aqui de legitimar uma postura - ortodoxa ou inovadora - mencionando os precedentes judiciais da CIJ para segui-los ou para se afastar deles ${ }^{99}$, em todo caso, sempre para falar das passarelas entre a ordem convencional dos direitos humanos e a ordem internacional geral. Será que podemos falar tecnicamente, aqui, de "diálogo" com a CIJ? Esta instância judicial é conhecida porque cede um lugar subsidiário (para não dizer quase inexistente) ao conteúdo do artigo $38 \$ 1 . \mathrm{d}$ do Estatuto do qual sabemos que ele autoriza a aplicação das "decisões de justiça”. Se ela gosta de ficar no "narcisismo jurisprudencial", ela mantém uma indiferença inacreditável para com a jurisprudência dos outros tribunais internacionais e nacionais $^{100}$. Fazendo isso, a jurisprudência da Corte de Estrasburgo não encontrou nenhuma adesão a suas longas decisões.

\section{0 ideal humanista}

Hoje, o direito é marcado pelos valores mais do que nunca ${ }^{101}$. Mesmo se eles não se resumem na proteção dos direitos fundamentais, é difícil negar seu lugar cada vez mais central no seio das ordens jurídicas nacionais e internacionais. Mas, olhando de longe, para tentar discernir as linhas fortes do diálogo solto, aparece, de maneira bastante fragrante, que ele tende a final, ao estabelecimento de uma coerência dos valores humanistas. O que é marcante, aqui, é o fato que todos os juízes, qualquer que seja seu ofício e seu sistema de referência, são tomados por este fortalecimento dos direitos. Isso não quer dizer que esta tendência seja livre de oposições, de recusas, em suma de conflitos. O caminho para o ideal é caótico

EDH, 6 de fevereiro de 2003, Mamatkulov e Askarov x Turquia e Corte EDH, Gde C., 4 de fevereiro de 2005, Mamatkulov e Askarov x Turquia).

${ }^{99}$ As ligações entre a Corte EDH e o direito internacional são tão fortes que resultam numa Crônica anual dirigida Por G. COHEN-JONATHAN e J-F FLAUSS no Annuaire français de droit international.

${ }^{100} \mathrm{O}$ artigo de M. Kamto é, neste ponto, um dos mais esclarecedores, escrito, além disso, num estilo muito elegante e impactante já que a expressão "narcisismo jurisprudencial" é sua, ver "As interações das jurisprudências internacionais e das jurisprudências nacionais", La juridictionnalisation du droit international, Paris, Pedone, 2003, p. 393-460.

${ }^{101} \mathrm{Eu}$ o remeto, neste ponto, ao curso ministrado por Mireille Delmas-Marty ao longo do primeiro semestre de 2008 no Collège de France em que se tratou dos "valores", ou melhor, das "comunidades de valores" (www.collegedefrance.org). 
e, com certeza, não linear: a universalidade dos direitos, de seu conteúdo, de seu alcance, não é aceita por todos e em toda parte. Com efeito, existem juízes que recusam o diálogo (ignorando pura e simplesmente os Outros juízes); outros, ao contrário, entram no jogo do "comércio judicial” para, na verdade, melhor refutar a incorporação de valores que eles não aceitam.

Vamos começar por um diálogo entre os mais conhecidos: aquele localizado de baixo de nossos olhos - i.e. na Europa - entre as duas Cortes supranacionais. Uns poucos representando aqui os ingênuos - para não dizer os Hurons ${ }^{102}$ - por que as Cortes de Luxemburgo e de Estrasburgo se abrem regularmente à jurisprudência da outra? A primeira atendeu o chamado urgente das Cortes constitucionais para responder a uma lacuna original dos tratados institutivos; fazendo isso, graças à técnica comprovada dos princípios gerais do direito, ela acabou dando um lugar de destaque à Convenção e, depois à jurisprudência da Corte europeia. Aí também, haverá de convir que não existia nenhuma obrigação imposta pelo sistema como era previsto na origem; que nenhuma concorrência dos modelos estava ou está em jogo; todavia, as obrigações (aparentemente “invisíveis") induzidas pelo sistema de integração o conduziram a levar em conta o chamado das Cortes internas, o que o levou a valorizar as decisões da Corte de Estrasburgo... Da mesma forma, quando esta última se refere à jurisprudência comunitária e que ela lhe atribui um lugar de destaque nas suas decisões, é grosso modo, na maioria dos $\operatorname{casos}^{103}$ para exportar no sistema convencional, apesar das diferenças de natureza e de objetivos que existem entre os dois universos, uma noção que lhe permite aceitar o desafio da compatibilidade ${ }^{104}$. Dessas complexas interferências nasceram emaranhamentos e interconexões múltiplas que ligam as duas cortes, que são obrigadas (para não dizer: condenadas...) a garantir in fine a homogeneidade sobre o

\footnotetext{
${ }^{102}$ Como não pensar, aqui, a um artigo famoso que, quando eu era estudante, tinha me cativado: "Um Huron no Palais Royal".

${ }^{103} \mathrm{Na}$ realidade, as nuances, aqui, seriam numerosas, pois os casos são variados. Todavia, tento ir ao essencial.

${ }^{104}$ Penso, por exemplo, na jurisprudência Pellegrin x França de 1996 em que a Corte se reapropria a noção comunitária de "funcionário". Mais recentemente, no caso muito importante D.H. e outros x República Checa de 13 de novembro de 2007, é a noção de "discriminação indireta" como ela foi posta pelos textos de direito derivado e a jurisprudência comunitária que é retomada pela Grande Câmara da Corte de Estrasburgo.
} 
continente europeu dos direitos fundamentais e dos conceitos associados ${ }^{105}$. Apesar da ausência de obrigação jurídica e enquanto a União Europeia de um lado e o Conselho da Europa do outro não deviam a priori ser ligados a este ponto - e até pés e punhos atados - a selva das obrigações acabou ganhando uma necessária e saudável abertura ao outro dos dois conjuntos. A mesma constatação é válida para o diálogo que se estabeleceu entre as Cortes interamericana e europeia dos direitos humanos. No entanto, é preciso começar dizendo que a corrente fluía num primeiro momento, num único sentido: a Corte de San José, bem cedo e de forma densa, não hesitou em se apoiar sobre a jurisprudência de sua colega de Estrasburgo. Era simplesmente questão de garantir a legitimidade de suas decisões escondendo-se atrás de uma jurisprudência mais antiga, mais conhecida e, consequentemente, dotada de uma "autoridade" incontestável. Todavia, o diálogo sucedeu à importação legitimadora pura e simples. Hoje, a Corte europeia - auxiliada, aliás, pelas informações repassadas pelas amici curiae - não ignora mais os avanços originais de sua colega interamericana ${ }^{106}$. Isso resultou numa harmonização da interpretação dos direitos, apesar das especificidades inerentes aos sistemas convencional americano e europeu.

Fundamentalmente, penso que a mesma constatação global se impõe para decifrar o diálogo entre as Cortes supremas dos países de common law, entre estas e a Corte europeia dos direitos humanos ${ }^{107}$ ou ainda entre esta última e os tribunais

\footnotetext{
${ }^{105}$ Todavia, não seria bom que as duas Cortes entrem num "acompanhanismo" que baixaria o nível de proteção. As decisões emblemáticas do que poderia ser qualificado com severidade como "acompanhanismo"... são as decisões da Corte de Estrasburgo de 30 de junho de 2005, Bosphorus Hava x Irlanda (que outorga ao sistema comunitário de proteção dos direitos uma patente de convencionalidade, reservando-se, no entanto, uma saída para uma eventual condenação no caso de insuficiência manifesta da proteção jurisdicional) e a decisão da Corte de Luxemburgo de 22 de setembro de 2006, Espanha x Reino Unido que valida a reforma do direito eleitoral britânico que tinha como objetivo tirar as conseqüências da decisão de condenação Matthews x Reino Unido de 1999.

${ }^{106}$ É o caso, por exemplo, em matéria de desaparecimentos forçados, Corte EDH, Gde Câm. 8 de julho de 1999, Cakici c. Turquia; Corte EDH, 9 de maio 2000, Ertak x Turquia; Corte EDH, 13 de junho 2000, Timurtas x Turquia. É sintomático constatar que a grande ONG Cejil (o Centro para a justiça e o direito internacional, ator maior do sistema interamericano de proteção dos direitos) se apresenta como amici curiae para fazer conhecer aos juizes europeus a riqueza da jurisprudência interamericana sobre esta questão.

${ }^{107}$ W. Schabas, "L'influence de la Convention européenne des droits de l'homme sur la jurisprudence des Cours suprêmes du Commonwealth", A influência da Convenção europeia dos direitos humanos sobre a jurisprudência das Cortes supremas.
} 
penais internacionais ${ }^{108}$. As vertentes procedurais e materiais dos direitos estão no centro das trocas. Agora, vamos explorar rapidamente estes dois elementos, se quiser.

O diálogo permite constatar a difusão do que foi chamado um "modelo" do processo equitativo $^{109}$. Nesse âmbito, a questão do direito de acesso ao juiz - parte integrante do processo equitativo - está no centro de todas as atenções, já que constitui nada menos do que a chave de entrada para uma proteção efetiva dos direitos substanciais. Aliás, a Europa se encontra a esse respeito num dilema próprio dos conjuntos democráticos: pode-se, em nome da luta contra o terrorismo, afastar o direito ao juiz, a ponto de maltratá-lo na sua substância? O desafio, aqui, é nada menos do que uma questão de identidade. Com efeito, estão em jogo os princípios fundadores da identidade europeia que se apoia no respeito dos direitos fundamentais. Mas, se a circulação do "modelo do processo equitativo" é incontestável, sua efetividade não é garantida definitivamente num mundo que muda, instável, complexo, sacudido por exigências contraditórias. Mas, hoje, a Europa vacila, tenta encontrar um equilíbrio, não sem dificuldade; não sem atropelar seus valores. $\mathrm{O}$ legislador da União agindo, com efeito, com certa desenvoltura com o respeito dos direitos da pessoa ${ }^{110}$, enquanto que o juiz, ele, faz o que ele pode, inclusive de forma desajeitada, para preservar a identidade constitucional da União ao direito ao juiz um lugar de destaque no seio das normas de jus $\operatorname{cogens}^{111}$. Se a solução não se encontra preservada das críticas - principalmente porque ela voltou a validar

${ }^{108}$ A. Cassese, "La prise en compte de la jurisprudence de Strasbourg par les juridictions pénales internationales", Le rayonnement international de la jurisprudence de la Cour européenne des droits de l'homme, G. Cohen-Jonathan, J-F. Flauss (dir.), Bruxelles, Bruylant, 2005, p.29-82.

${ }^{109} \mathrm{C}$. Girard, "Procès équitable et enchevêtrement des espaces normatifs (Réflexions sur la problématique générale)," H. Ruiz-Fabri (dir.), Procès équitable et enchevêtrement des espaces normatifs, Paris, Société de Législation Comparée, 2003, p.21-51.

${ }^{110} \mathrm{H}$. Labayle, «Droits de l'homme et sécurité intérieure de l'Union européenne, l'équation impossible», RAE, 2006-1, p.93-109 ; R. Tiniere, «La collaboration de certains Etats européens au programme de restitutions extraordinaires de la CIA en Europe et la protection européenne des droits fondamentaux », RAE-LEA, 2006-2, p.537-556.

${ }^{111}$ Esta temática, sabemos até demais, é, na substância, aquela dos famosos casos Yusuf, Kadi, Hassan TPICE., 21 de setembro de 2005, Ahmed Ali Yusuf e Al Barakaat International Foundation $\mathbf{x}$ Conselho da União europeia e Comissão das Comunidades europeias, caso T-306/01, rec., p. II-3533; TPICE, 21 de setembro de 2005, Yassin Abdullah Kadi x Conselho da União europeia e Comissão das Comunidades europeias, caso T-315/01, rec., p. II-3649; TPICE, 12 de julho de 2006, Chafiq Ayadi x Conselho da União europeia, caso T-253/02 ; TPICE 12 de julho de 2006, Faraj Hassan x Conselho 
a regulamentação comunitária ${ }^{112}$, ela é, também, reveladora de uma vontade de tornar "concreta e efetiva" a noção de "união de direito", sobretudo na adversidade. Por sua vez, os Estados-Unidos já decidiram, mas de forma paradoxal.

A jurisprudência da Corte suprema é atravessada por um hiato importante. Por um lado, a instância judicial suprema acabou reconhecendo aos prisioneiros de Guantánamo o direito de contestar a legalidade de sua detenção diante dos tribunais civis americanos, aproveitando disso para fustigar a ação do Congresso, que tinha desejado contornar as decisões da Corte $^{113}$. Do outro lado, no caso Medellín $x$ Texas $^{114}$, ela recusava que a importante decisão Avena ${ }^{115}$, pronunciada pela Corte

da União europeia e Comissão das Comunidades europeias, caso T-49/0. Ver o estudo aprofundado de P. Stangos e de G. Gryllos - «Le droit communautaire à l'épreuve des réalités du droit international: leçons tirées de la jurisprudence communautaire récente relevant de la lutte contre le terrorisme international», CDE, 2006, nº3-4, p. 429-482.

${ }^{112} \mathrm{O}$ dilema, hoje, se apresenta da seguinte forma: a Corte de justiça vai - no âmbito do recurso do histórico caso Yusuf /Al Barakaat International Foundation - renegar seus valores e aceitar que um regulamento comunitário que implantou uma resolução do Conselho de segurança, sem que pessoas e entidades, consideradas como sendo "terroristas" pudessem se defender diante de um tribunal independente, possa continuar válido? Ela vai acompanhar a argumentação do TPI, que - elevando vários direitos fundamentais, notadamente o direito ao juiz, ao nível de norma de jus cogens - apesar disso, validou o regulamento comunitário ou ela vai acompanhar as corajosas conclusões do advogado geral Miguel Poiares Maduro que, restituindo a problemática no campo dos direitos fundamentais, propõe a anulação tanto da decisão do tribunal de primeira instância quanto aquela do regulamento comunitário? Conclusões do Advogado Geral Miguel Poiares Maduro apresentadas no dia 23 de janeiro de 2008 no caso Al Barakaat International Foundation, C-415/05 P.

${ }^{113}$ Corte Suprema dos Estados-Unidos, 12 de junho de 2008, Boumedienne x Bush, n $\mathrm{n}^{\circ}$ 1195. Este caso se situa na lógica das decisões tomadas em 2004 e 2006 que o Congresso, entre as mãos dos "neo-conservadores", tinha sistematicamente contornado. As duas decisões pioneiras de 2004 consideravam que tanto os "combatentes inimigos" (cidadãos americanos presos no âmbito da guerra contra o terrorismo) quanto os "combatentes irregulares" (detentos não-americanos) deviam poder ter acesso à justiça civil americana, $v$. Corte Suprema dos Estados-Unidos, 28 de junho de 2004, Hamdi $x$ Rumsfeld, n03/6696; Corte Suprema dos Estados-Unidos, 28 de junho de 2004, Rasul x Bush, n03/334. Para uma visão geral da posição dos Estados-Unidos para com a Justiça Internacional, me permito remetê-lo a um estudo que foi muito interessante a escrever, "Les Etats-Unis d’Amérique et la justice internationale. Entre l'utilisation et l'instrumentalisation du droit international », Le droit international à la croisée des chemins. Force du droit et droit de la force, R. Ben Achour, S. Laghmani (dir.), Paris, Pedone, 2004, p.233-269.

${ }^{114}$ Corte Suprema dos Estados-Unidos, 25 de março de 2008, Medellín x Texas, nº6-983.

${ }^{115} \mathrm{CIJ}, 31$ de março de 2004, Fundo Avena e outros cidadões mexicanos (México x EstadosUnidos), x M. Benlolo-Carabot, AFDI, 2004. 
internacional de Justiça no âmbito do contencioso consular, ligue os tribunais norte-americanos ${ }^{116}$, o que não deixou de fazer reagir viva e rapidamente alguns membros da Assembleia Parlamentar do Conselho da Europa ${ }^{117}$. O autismo para com o direito internacional e vindo das decisões de justiça internacionais é uma constante da cultura judicial americana ${ }^{118}$ : o municipal law deve, com efeito, ganhar perante o international law $w^{119}$.O diálogo é marcado por discordâncias reveladoras da impossibilidade de definir uma visão universal e intemporal do significado do acesso ao direito, a mesma constatação caótica pode ser estabelecida para o significado do conteúdo e do alcance dos direitos. Por um lado, o diálogo solto põe à luz do dia a emergência de linhas de força sobre problemáticas que afetam todas as sociedades. O sexo, a vida e a morte são, portanto, questionamentos que, quaisquer que sejam os recantos do planeta, conduzem os juizes a "deslocar os olhares" e procurar soluções estrangeiras, internas ou internacionais. A questão da homossexualidade (que resulta naquela da homoparentalidade); a problemática do fim de vida (que induz a da eutanásia ou ainda da pena de morte); a temática do início da vida (e daí do estatuto dos nascituros), são interrogações existenciais que enervam as conversas judiciais. Sobre todas essas questões, os pontos de encontros existem, às vezes com sérias adaptações, para não dizer posições firmes. O que está certo é que os juizes se abrem às decisões estrangeiras: eles podem usá-las para seu conforto para os únicos fins de fortalecer uma argumentação interna, ou então, de forma mais audaciosa, no objetivo claro de operar uma magistral mudança de rumo. Foi o caso, notadamente, quando, quebrando todos os códigos e tradições judiciais, a

\footnotetext{
${ }^{116}$ Para a indignação do juiz Breyer que, em sua opinião dissidente, apoiou-se, entre outras coisas, em algumas decisões de justiça estrangeiras, assim como em certas disposições constitucionais (sobretudo a Constitução dos Países-Baixos) para recusar a argumentação majoritária.

${ }^{117}$ Ver a proposta de Resolução apresentada pelo deputado belga Luc Van Den Brande, apoiada por quatorze outros parlamentares no dia 2 de maio de 2008 (Doc. 11606). Os itens 4 e 5 são redigidos assim: " 4 . De acordo com a Assembleia, a decisão precitada da Corte suprema implica num inaceitável desprezo do direito internacional e uma recusa manifesta em se conformar às obrigações dos Estados-Unidos para com a Carta das Nações Unidas. 5. É por isso que a Assembleia incentiva fortemente os Estados-Unidos a se conformarem a seus comprometimentos internacionais garantindo, através de meios de sua escolha, um reexame efetivo das condenações dos cidadãos mexicanos citados na decisão Avena, assim como a mais alta jurisdição internacional o ordenou."

${ }^{118}$ D. Vagts, «The United States and its Treaties: Observance and Breach», 95, AJIL 2001, p. 313.

${ }^{119}$ M.N. Shaw. International Law. 5. ed. Cambridge, University Press, 2003. p. 143-151.
} 
Corte suprema americana apropriou-se do caso Dudgeon ${ }^{120}$, para pôr um fim à sua jurisprudência que, durante décadas, tinha dado seu aval à penalização da homossexualidade. Se o caso Lawrence $x$ Texas $^{121}$ foi o marco de uma pequena revolução, não devemos, também não, ver nele o advento de uma nova "era”. A Corte foi dividida e as reações no mundo político americano foram excessivamente violentas ${ }^{122}$. Retorna-se à ideia da complexidade do real, difícil de apreender.

Da mesma forma, o diálogo solto dos juízes que empregam a noção de jus cogens para proibir a transgressão de certas normas - como a proibição da tortura, do genocídio, dos desaparecimentos, mas também da não discriminação ou ainda do direito ao juiz ${ }^{123}$ - revelam também a emergência, mesmo que caótica, de uma “comunidade de valores” de acordo com a expressão de Mireille Delmas-Marty. Os direitos econômicos e sociais não são nem um pouco descartados nessas entrevistas judiciais. $\mathrm{O}$ direito à hospedagem ou, ainda, o "direito à comida" (the right to food) estão no centro das tensões sociais que agitam as sociedades, que sejam elas desenvolvidas ou em via de desenvolvimento; uma vez mais, os juízes são levados a acompanhar com atenção os sobressaltos jurisprudenciais sobre essas questões, para se inspirar nelas ou, ao contrário, se afastar delas; em todo caso, frequentemente, para fazer uma referência a elas.

\footnotetext{
${ }^{120}$ Corte EDH, 22 de outubro de 1981, Dudgeon $x$ Reino-Unido.

${ }^{121}$ Corte Suprema dos Estados-Unidos, 26 de junho de 2003, Lawrence x Texas.

${ }^{122}$ A resolução adotada pela Câmara dos Representantes no dia 17 de março de 2004 (H. Res. 568) revela a importância da polêmica suscitada do outro lado do Atlântico.

${ }^{123} \mathrm{O}$ Tribunal penal internacional para a ex-Iugoslávia (TPIY), no caso Anto Furundzija de 10 de dezembro de 1998, $\$ 154$, afirmava: A qualificação de uma norma de jus cogens tem um "efeito de dissuasão no sentido que ela lembra a todos os membros da comunidade internacional e aos indivíduos nos quais têm autoridade que se trata de um valor absoluto que ninguém pode transgredir." (n ${ }^{\circ}$ IT-95-17/1-T). Tratava-se, neste caso, da proibição da tortura. A solução foi retomada pela Corte europeia dos direitos humanos que se referiu diretamente à decisão do TPIY (Corte EDH, 21 de novembro de 2001, Al-Adsani x ReinoUnido). A Corte interamericana não demorou a se inserir neste diálogo intercontinental, Corte IDH, 11 de março de 2005, Fundo e reparações, Caesar x Trindade e Tobaggo, Série $\mathrm{C}^{\circ}{ }^{123}$. Ela foi particularmente audaciosa estabelecendo o princípio de igualdade e de não-discriminação em nome de jus cogens no seu famoso parecer, consequência de uma ação junto ao governo mexicano (Corte IDH, 17 de setembro de 2003, Parecer, Condião jurídica e direito dos trabalhadores migrantes em situação irregular, Série $\mathrm{A} \mathrm{n}^{\circ} 18$ ). Em casos históricos do ano de 2006, é ao mesmo tempo o acesso ao juiz e a proibição dos desparecimentos forçados que eram estabelecidos em nível de normas de jus cogens (Corte
} 
No universo dos países ligados à common law, a África do Sul se encontra na vanguarda da "abertura”. Após o famoso caso Grootboom que impõe ao Estado, em matéria de direito à hospedagem, obrigações de agir em situações extremamente sérias $^{124}$, é a vez do caso Mazibuko de ser a marca de uma jurisprudência receptiva às influências externas: aquela do direito internacional como tal, mas também das jurisprudências nacionais estrangeiras. São, ao mesmo tempo, decisões brasileiras, argentinas, francesas (sim, caro Presidente... francesas) e britânicas que foram empregadas pelo juiz supremo sul-africano para declarar como sendo inconstitucional um sistema de pré-pagamento da água e para impor ao Estado a necessária realização progressiva de um acesso à água potável ${ }^{125}$.

Caro Presidente, o que lhe dizer para fechar esta volta que pode dar um sentimento de vertigem? Nada que seja garantido ou definitivo. Apesar do fato de haver tendências perceptíveis, elas nunca são lineares, daí a grande dificuldade em pensar certo. Estou convencida que o diálogo, que se torna planetário, lança um desafio aos pesquisadores e aos práticos. O resultado é que se deve estar à altura de tais desafios analíticos e práticos. São, de qualquer forma, belas perspectivas de pesquisa que se anunciam e que vão manter tanto as entrevistas judiciais quanto as nossas entrevistas doutrinais.

IDH, 22 de setembro de 2006, Fundo e reparações, Boigurrú x Paraguay Série C n 153 e Corte IDH, 29 de novembro de 2006, Fundo e reparações, La Cantuta x Peru, Série C $\mathrm{n}^{\circ} 162$ ). Mas, a ousadia (alguns diriam a inconsciência) não vem somente das Américas. Nós conhecemos as decisões do TPICE que colocam ao lugar de norma de jus cogens, ao mesmo tempo, o direito de propriedade, os direitos da defesa e last but not least (como a Corte de San José) o direito ao recurso jurisdicional efetivo (TPICE, 21 de setembro de 2005, Ahmed Ali Yusuf, Barakaat International Foundation, T-306/01; TPICE, 21 de setembro de 2005, Kadi, T-315/05; TPICE, 12 de julho de 2006, Ayadi, T-253/02; TPICE, 12 de julho de 2006, Hassan, T-49/04; TPICE, 31 de janeiro de 2007, Minin, T-362/04). Aqui, não posso apresentar todas as "revelações judiciais" das normas de jus cogens. Eu chamaria sua atenção sobre o fato que, após o TPIY no caso Goran Jelic, a CIJ acabou saindo de sua lendária reserva afirmando no dia 13 de janeiro de 2006, no caso opondo à instância da República do Congo ao Ruanda que "o conflito concerne o respeito de uma norma [a proibição do genocídio] possuindo (com certeza) o caráter de uma norma de [jus cogens]". (\$64)

${ }^{124}$ Corte Suprema da África do Sul, 4 de outubro de 2000, República da África do Sul x Grootboom e outros, $\mathrm{n}^{\circ} 11 / 2000$.

${ }^{125}$ Corte Suprema da África do Sul, $1^{\circ}$ de maio de 2008, Mazibuko x Johannesbourg, $\mathbf{n}^{\circ}$ 06/13865, principalmente os $\$ \$ 86-91$. 


\section{The internationalization of the dialogue of judges: letter to Mr. Bruno Genevoi, Chairman of the Council of the State of France}

\section{Abstract}

This paper was invited and translated by the editorial of Prismas journal. The text discusses the internationalization process of law. The author follows a linguistic style letter addressed to the President of the French court considered one of the responsable for advancing the process of internationalization. The article makes a comparison between the developments in the internationalization process of the law of the Court of Human Rights and the European Court of Human Rights, in a context namely of dialogue of judges. Several judicial precedent are quoted and analyzed.

Keywords: Internationalization of Law. Human Rights. Dialogue of Judges. 